\title{
Taphonomy and paleoecology of fauna and flora from deltaic sandstones of Mospinka Formation (Middle Carboniferous) of Donets Basin
}

\author{
Vitaliy Dernov \\ Institute of Geological Sciences, NAS of Ukraine (Kyiv, Ukraine)
}

Taphonomy and paleoecology of fauna and flora from deltaic sandstones of Mospinka Formation (Middle Carboniferous) of Donets Basin. - V. Dernov. - The taphonomic and ecological features of the predominantly non-marine fauna and terrestrial flora from two deltaic sandstones in the middle part of the Mospinka Formation (Upper Bashkirian, Lower Pennsylvanian) were studied. The non-marine fauna of the Carboniferous of the Donets Basin is extremely poorly studied. Currently, many groups of animals living beyond the marine environment are known from here (non-marine bivalves, horseshoe crabs, eurypterids, arachnids, insects, ostracods, cirripeds, conchostracs, cycloids and fishes). They have great stratigraphic and paleogeographic significance. Fossil soils from the Bashkirian Stage of the Donets Basin were first studied. In the studied sandstones, the presence of the most ancient red-bedded sediments in the Carboniferous of the Donets Basin was noted. This circumstance, together with the specifics of the composition of communities of peat-forming plants, indicates that during the accumulation of deposits of the Mospinka Formation, against the background of a predominantly humid climate, episodes of temporary increase in climate dryness arose. Microbially induced sedimentary textures in the Carboniferous deposits of the Donets Basin were studied for the first time. For many taxa of fossil plants, the vertical distribution in the section of the Carboniferous of the Donets Basin is specified. The oldest community of non-marine bivalves in the Carboniferous of the so-called Open Donets Basin was studied. In both sandstone beds, the presence of remains and traces of locomotion of giant arthropods of the genus Arthropleura was recorded. Together with them, fossils of large horseshoe crabs and insects are observed. The composition of the richest ichnocenosis in the Carboniferous sediments of the Donets Basin was studied. Among ichnofossils, a trace of a tetrapoda locomotion, as well as traces of arthropods activity on plant organs should be especially noted. Deltaic deposits are rich in orictocenoses, which is associated with a variety of living conditions of organisms and the burial of their remains. The new data obtained are of great importance for reconstructing the living conditions of organisms at the sea-land boundary. The performed studies showed great prospects for studying the nonmarine fauna of the Carboniferous of the Donets Basin in order to corellate marine and continental sediments of the Carboniferous of Laurasia.

Key words: Ukraine, Pennsylvanian, taphonomy, paleoecology, fauna, flora, sandstones.

\section{Introduction}

The Donets Basin is a key region for improvement of Carboniferous stratigraphy of Euramerica. This is due to the completeness of the section and it richness in remains of marine and terrestrial organisms. Despite its significant scientific importance, the fossils from the Carboniferous deposits of the Donets Basin have been studied extremely unevenly. Only the groups of fossil organisms that are important for stratigraphy have been investigated in detail. Non-marine animals that are represented in the Carboniferous sediments of the Donets Basin by freshwater bivalves, horseshoe crabs, eurypterids, arachnids, insects, ostracods, cirripeds, conchostracs, cycloids, and fishes (Chernyshev, 1931; Sergeeva, 1969; Sharova and Sinichenkova, 1977; Dernov, 2015, 2016, 2018 etc.) are studied rather poorly due to their rarity or bad preservation.

For this reason, we have undertaken paleoecological and taphonomic studies of paleontological remains contained in sediments of transitional genesis of the Bashkirian Stage of the central part of the Donets Basin. Some results were published earlier (Dernov, 2015, 2016, 2018). Particular attention was paid to deltaic sandstones, which, as shown by analysis of literature sources, sometimes contain numerous remains of marine and terrestrial fauna and flora. Carboniferous sandstones of the Donets Basin have long been deprived of the attention of paleontologists. The reason for this is

Correspondence to: V. Dernov; Institute of Geological Sciences, NAS of Ukraine; Honchara St. 55 B, Kyiv, 01054 Ukraine; e-mail: vitalydernov@gmail.com; orcid: 0000-0002-5873-394X 
their comparatively large particle size, as well as significant porosity and other circumstances that prevented the conservation of fossil remains of organisms.

\section{Research history}

The remains of animals and plants from the Carboniferous deposits of the Donets Basin have been studied for about two centuries. Over this long period, numerous groups of non-marine animals and terrestrial plants were revealed from various parts of the Carboniferous section. To the study of fossil macroflora are dedicated the works by A. V Gurov, I. F. Shmalgauzen, N. V. Grigoriev, M. D. Zalessky, E. F. Chirkova, E. O. Novik, T. A. Ishchenko, A. K. Shchegolev, O. P. Fisunenko, N. S. Snigirevskaya, V. G. Lepekhina, and N. I. Boyarina. The palynoflora was studied by A. A. Lyuber, A. M. Ishchenko, K. I. Inosova, A. Kh. Kruzina, N. N. Podgainaya, E. G. Shvartsman, V. I. Levina, V. K. Teteruk, T. V. Byvsheva, and E. V. Semenova. The composition of peat-forming plants was determined by P. P. Shkurenko, A. M. Lapteva, A. V. Lapo, I. N. Drozdova, E. S. Korzhenevskaya, V. I. Uziyuk, N. A. Ignatchenko, K. I. Inosova, G. P. Vyrvich, G. P. Matsenko, T. G. Shendrik, M. D. Berdyukov, and A. M. Ishchenko (Zerov et al., 1972).

The works by B. I. Chernyshev, D. M. Fedotov, P. L. Shulga, and M. T. Sergeeva were devoted to the study of non-marine bivalves (Chernyshev, 1931; Shulga, 1948; Sergeyeva, 1969). Arthropods were described by S. V. Gorak (non-marine ostracods), B. I. Chernyshev (horseshoe crabs, eurypterids, cirripeds, conchostracs), N. N. Dunaeva (conchostracs), E. S. Shpinyov (horseshoe crabs and eurypterids), A. G. Sharov and N. D. Sinichenkova (insects), and P. Selden with co-authors (arachnids) (Selden et al., 2014; Shpinyov, 2018). The remains of fishes from non-marine sediments were studied by B. I. Chernyshev, A. V. Khabakov, N. S. Baleeva, A. F. Efimova, and N. N. Karlov (Dernov, 2018). There are reports of finds of microconchids in the Lower Pennsylvanian deposits of the Donets Basin (Dernov, 2018). Trace fossils from the Carboniferous of the Donets Basin are poorly studied. Ichnofossils were studied by Yu. I. Fedchenko, I. A. Tatoli, O. P. Fisunenko, and V. F. Shulga (Dernov, 2018). Some findings of remains of non-marine arthropods and fishes in the Pennsylvanian deposits were reported in our previous works (Dernov, 2015, 2016, 2018).

\section{Research area and stratigraphy}

The territory of the study is the upper part of the Bolshaya Kamenka river's basin (right tributary of the Seversky Donets - fig. 1, B). These studies focused on two thick sandstone beds in the middle part of the Mospinka Formation: $43 \mathrm{~m}$ below the $\mathrm{G}_{1}{ }^{2}$ limestone $\left(\mathrm{g}_{1} \mathrm{SG}_{1}{ }^{2}\right)$ and $4-5 \mathrm{~m}$ above it $\left(\mathrm{G}_{1}{ }^{2} \mathrm{Sg}_{1}{ }^{2}\right)$

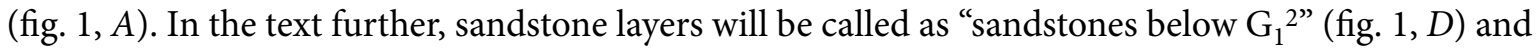
"sandstones above $\mathrm{G}_{1}{ }^{2}$ ". Their study is of considerable interest for restoring the living conditions of Carboniferous animals and plants at the border of the sea and land.

The Mospinka Formation is represented by cyclic interbedding of mudstones, siltstones, sandstones with a subordinate value of limestones (8 layers) and coal (10-12 layers) (Nemyrovska, Efimenko, 2013). The age of this stratigraphic unit is Late Bashkirian (Early Pennsylvanian). The absolute age of the sole and roof of the formation is about 318.5 and 317 million years, respectively (Davydov et al., 2010). The thickness of the Mospinka Formation is 315-730 m (Nemyrovska, Efimenko, 2013).

Paleontological material comes from sandstones exposed by small quarries and natural outcrops near Makedonovka village (Lutugino Raion, Lugansk Oblast - fig. 1, $B, C$ ).

The studied outcrops are located on the northern border of the Kolpakovo-Nagolchansk structural-facies zone (SFZ) (Poletaev et al., 1991). It occupies the near-axis part of the Donets Trough (Poletaev et al., 1991). Within this SFZ, mainly clayey sediments of the Dyakovska Series are widespread, which accumulated in a rapidly saging narrow trough (Poletaev et al., 1991). Its central part was characterized by hydrogen sulfide contamination of sediments and/or bottom waters. To the periphery of the trough, sediments become more shallow water and signs of $\mathrm{H}_{2} \mathrm{~S}$ content in them disappear. Gradually, they are replaced by coal-bearing sediments of Serpukhovian and Bashkirian Stages. 

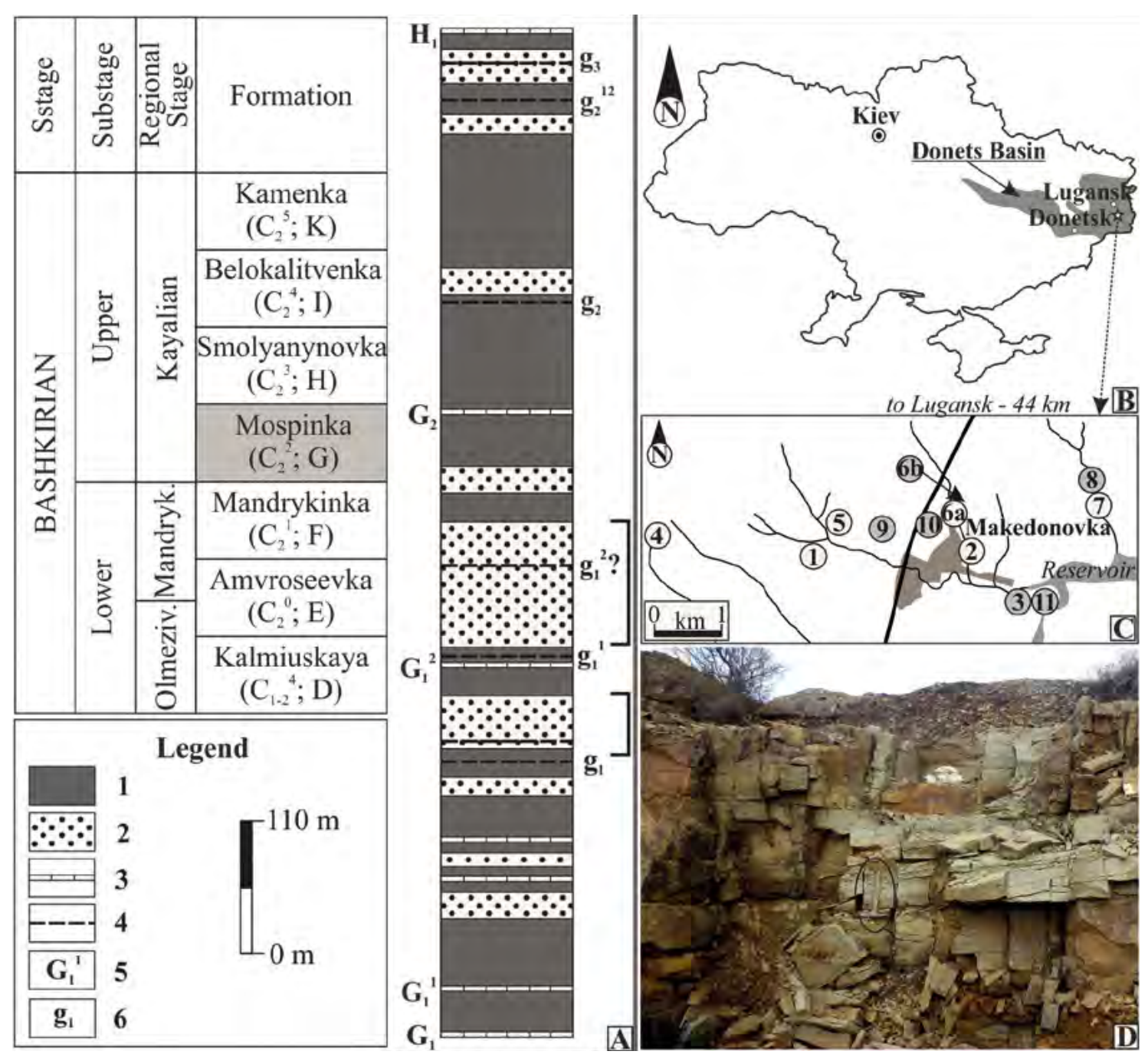

Fig. 1. The stratigraphic $(A)$ and geographic $(B, C)$ position of the studied outcrops and sandstones on the outcrop $1(D)$. Legend: 1 - siltstones and mudstones, 2 - sandstones, 3 - limestones, 4 - coals, 5 - limestones indices, 6 - coals indices, dark gray circles - outcrops of sandstone above $\mathrm{G}_{1}{ }^{2}$, light gray circles - outcrops of sandstone below $\mathrm{G}_{1}{ }^{2}$. Abbreviations: Olmeziv. - Olmezivkian, Mandryk. - Mandrykian. The lithological column is taken from Nemyrovska, Efimenko, 2013.

Рис. 1. Стратиграфічне $(A)$ та географічне $(B, C)$ положення вивчених відслонень та пісковики відслонення $1(D)$. Умовні позначки: 1 - алевроліти та аргіліти, 2 - пісковики, 3 - вапняки, 4 - кам'яне вугілля, 5 - індекси вапнякових шарів, 6 - індекси вугільних шарів, темно-сірі круги - відслонення пісковику вище вапняку $\mathrm{G}_{1}{ }^{2}$, світло-сірі круги - відслонення пісковику нижче вапняку $\mathrm{G}_{1}{ }^{2}$. Скорочення - Olmeziv. - олмезівський регіоярус, Mandryk. - мандрикинський регіоярус. Літологічну колонку взято з роботи (Немировська, Єфіменко, 2013).

According to Poletaev et al., 1991, the northern boundary of the Kolpakovo-Nagolchansk SFZ passes along the axis of the Northern anticline of the Central zone of large linear foldings. Nevertheless, we noted the presence of sediments of the Dyakovska Series on the northern wing of this anticline, where they correspond to the lower part of the Mospinka Formation. Within the Kolpakovo-Nagolchansk SFZ, sandstones above and below the $\mathrm{G}_{1}{ }^{2}$ limestone are equivalent to deposits of submarine fans, previously interpreted by O. P. Fisunenko and A. I. Reznikov (1985) as "sediments of the sea current zone". 


\section{Lithological features of deposits}

Paleosols. The structure of the studied sandstones involves paleosols (Beznosov et al., 2018). Their stratigraphic position is shown in figs 2 and 3. The presence of paleosols has been repeatedly mentioned in the Pennsylvanian deposits of the Donets Basin. A monograph by A. P. Feofilova (1975) is devoted to their study. Unfortunately, this work does not present the results of studying the paleosols of the Bashkirian Stage. Some of the studied paleosols are described below.

PS-1/1. Paleosol lies with a sharp contact on the avandeltaic sandstones. The profile is composed of grayish yellow and gray, fine-grained sandstones. Ripple marks are observed on the lower surface of the layer. Thikness is $1.2 \mathrm{~m}$.

Primary layering of sediments is disturbed by the activity of plant root systems. In the lower part of the profile, abundant rhizolites are found (fig. 4, 1,2). They are developed according to the appendix of Stigmaria. Rhizolites are represented by tubular and conical covers consisting of iron oxides with a central channel made of darker iron oxides and hydroxides, and sometimes also quartz. Their length usually does not exceed $5 \mathrm{~cm}$. Below the brown ironstone interlayer in the lower part of paleosol profile, the sandsone becomes calcareous and the number of rhizolites decreases.

Gleying of the soil profile probably occurred by appendixes of Stigmaria. We tend to interpret the described tubes as the consequences of excessive moisture, which led to the development of reducing conditions and gleying of the profile. The confinement of the tubes to the lower part of the profile may indicate that the gleying process occurred most intensively in this part. The described rhizolites, according to the classification proposed in Klappa, 1980, are the closest to the "root casts". The upper part of the profile is washed away. In the upper part of the profile, a trace fossil was found identified as Planolites isp. It is difficult to say whether this bioturbation is a trace of soil fauna or whether it occurred after conservation of paleosol by overlying sediments.

Fig. 2. Sections of the sandstones below the $\mathrm{G}_{1}^{2}$ limestone, exposed by outcrop $1(A)$, outcrop $2(B)$, shales above layer no. 5 of outcrop $1(C)$, limonite nodules from layer no. 17 of outcrop $11(D)$, pebble of metamorphic slate from layer no. 9, outcrop $1(E)$, cross-bedded sandstones (layer no. 4, outcrop 1) $(F)$. Legend (for $A, B$ ): 1 - sandstone, 2 - siltstone, 3 - interlayer of siltstone, $4-$ mudstone, 5 - coal bed, 6 - megaconcretion, 7 - siderite nodules (a) and limonite nodules (b), 8 - pebbles, 9 - the plant remains (branches, phyloids, shoots, etc.), 10 - rhizophores Stigmaria with appendixes (in situ), 11 - appendices Stigmaria without the rhizophores (in situ), 12 - the root systems of horsetails, 13 - large coalified trunks, 14 - textures of microbial mats, 15 - ?jellyfishes, 16 - non-marine bivalves, 17 - marine bivalves, 18 - gastropods (Belerophontidae), 19 - crinoids, 20 - indefinite remains of arthropods, 21 - horseshoe crabs, 22 - Arthropleura, 23 - insects, 24 - fishes, 25 - fecal pellets, 26 - trace fossils (except fecal pellets), 27 - ripple marks and wavy layering, 28 - horizontal lamination, 29 - cross-bedded layering, 30 - horizontal and cross-bedded layering, 31 thin lamination, 32 - wavy and horizontal lamination, 33 - phytoturbation of sediments, 34 - bioturbation of sediments by animals, 35 - ferruginous rocks, 36 - pyritization of rocks, 37 - rhizolites, 38 - ichnofabric index (number of points on a five-point scale), 39 - the number of meters of section thickness not shown in the figure, 40 - paleosols.

Рис. 2. Розрізи пісковикових пачок нижче вапняку $\mathrm{G}_{1}{ }^{2}$, що представлені на відслоненні $1(A)$, відслоненні $2(B)$, сланці вище шару № 5 відслонення $1(C)$, лимонітові конкреції з шару № 17 відслонення $11(D)$, галька метаморфічних сланців з шару № 9 відслонення $1(E)$, косошаруваті пісковики (шар № 4, відслонення 1) $(F)$. Умовні позначки (для $A, B): 1$ - пісковик, 2 - алевроліт, 3 - прошарок алевроліту, 4 - аргіліт, 5 - вугільний шар, 6 - мегаконкреція, 7 - сидеритові (a) та лимонітові (b) конкреції, 8 - галька, 9 - рештки рослин (гілки, філоїди, пагони та ін.), 10 - ризофори Stigmaria з апендиксами (in situ), 11 - апендикси Stigmaria без ризофорів (in situ), 12 - коренева система хвощеподібних, 13 - великі вуглефіковані стовбури, 14 - мікробіально-індуковані осадові текстури , 15 - ?медузи, 16 - неморські пелециподи, 17 - морські пелециподи, 18 - гастроподи (Belerophontidae), 19 - морські лілеї, 20 невизначені рештки членистоногих, 21 - мечохвости, 22 - Arthropleura, 23 - комахи, 24 - риби, 25 фекальні пелети, 26 - іхнофосилії (за виключенням фекальних пелетів), 27 - знаки хвиль та хвиляста шаруватість, 28 - горизонтальна шаруватість, 29 - коса шаруватість, 30 - горизонтальна та коса шаруватість, 31 - тонка шаруватість, 32 - хвиляста та горизонтальна шаруватість, 33 - фітотурбація, 34 - біотурбація осадів тваринами, 35 - породи, що збагачені оксидами та гідроксидами заліза, 36 піритизація порід, 37 - ризоліти, 38 - індекс біотурбації (кількість балів за п’ятибальною шкалою), 39 - кількість метрів потужності розрізу, що не показані на рисунку, 40 - викопні грунти. 


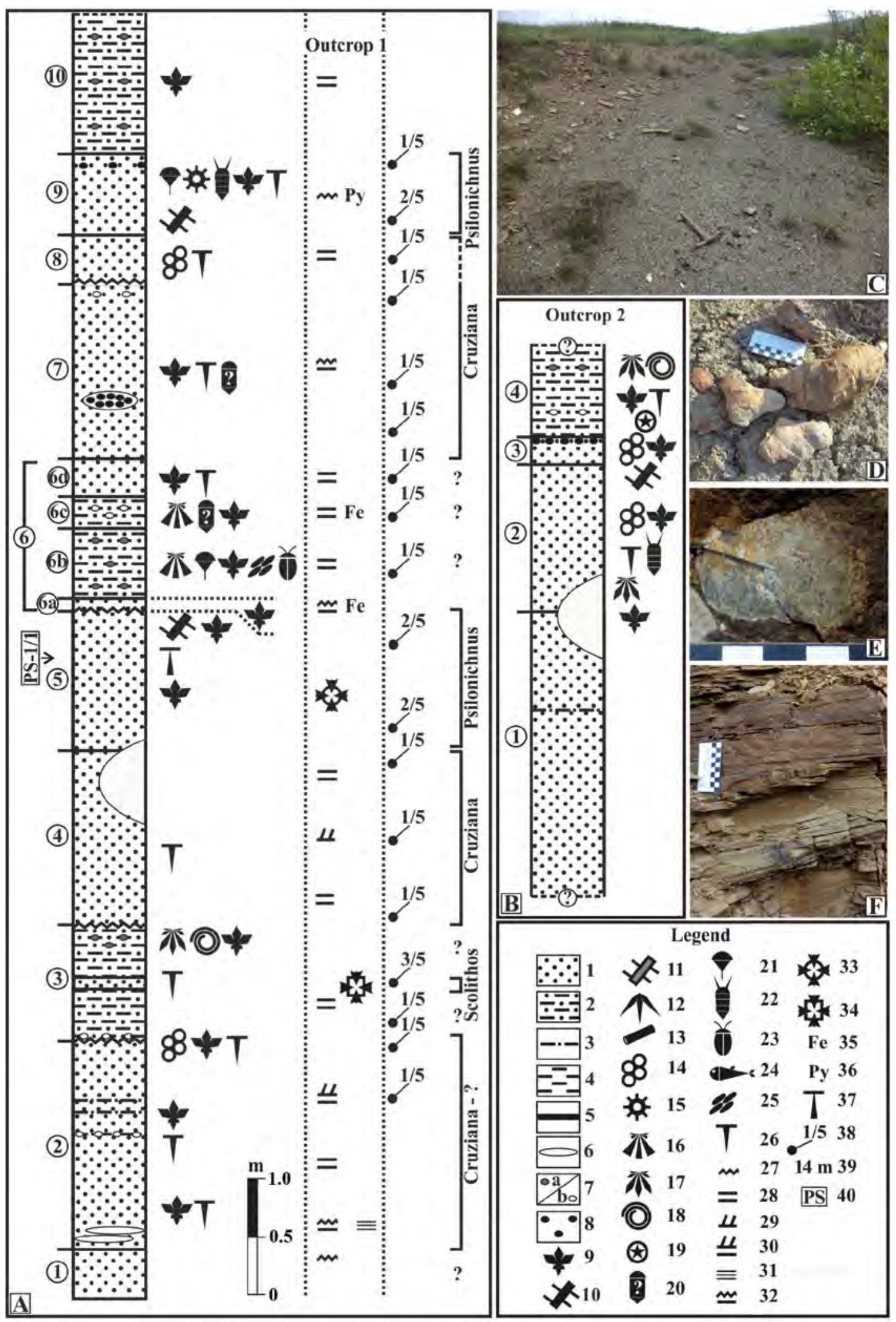



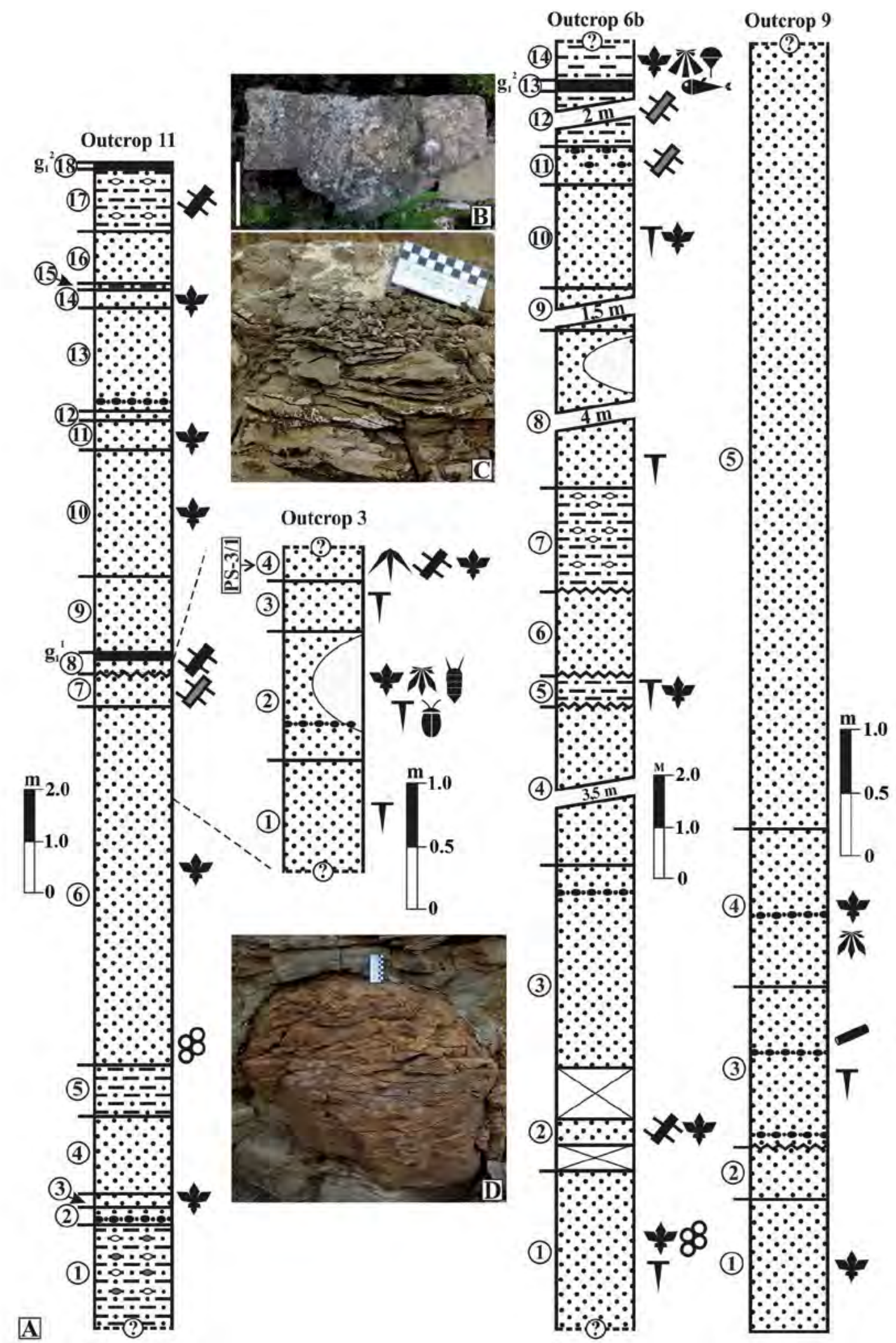
$\leftarrow$ Fig. 3. Lithological sections of the sandstones above the limestone $\mathrm{G}_{1}{ }^{2}$, wich are exposed by outcrop $3,6 \mathrm{~b}, 9$ and $11(A)$, trace fossil ? Conichnus isp. (perpendicular to the layering plane) in the sandstones of layer no. 3, outcrop $9(B)$, the paleosol PS $-3 / 1(C)$, megaconcretion of carbonate sandstone in layer no. 2 outcrop $3(D)$. Legend see fig. 2. The length of the scale bar/line in the photo is $100 \mathrm{~mm}$.

Рис. 3. Літологічний розріз пачки пісковиків вище вапняку $\mathrm{G}_{1}^{2}$, що представлений на відслоненнях 3, 6b, 9 та $11(A)$, іхнофосилія ?Conichnus isp. (перпендикулярно відносно площини нашарування) у пісковиках шару № 3, відслонення $9(B)$, викопний грунт PS-3/1 (C), мегаконкреція карбонатного пісковику в шарі № 2 відслонення $3(D)$. Умовні позначки - див. рис. 2. Довжина масштабної шкали/ відрізку на фото - 100 мм.

PS-1/1a. The paleosol is represented by a layer of non-lithified clays and sands with a thickness of $0.4 \mathrm{~m}$ (fig. 4, 3). In the western part of the outcrop 1, these rocks overlap by lagoonal siltstones. Apparently, carbonat pedonodules are in the base of these siltstones, wich were redeposited from paleosol (fig. 4, 12). Thus, after the formation of the paleosol PS-1/1, a short break occured. Then the formation of paleosol PS-1/1a started. Later this paleosol was partially eroded by waters of the shallow water lagoon.

PS-2/1. The paleosol lies with abrupt contact on the avandeltaic sediments. The profile is represented by grayish-green and yellowish-gray sandstone, phytoturbated, fine-grained with frequent appendics of Stigmaria and rare limonite rhizolites. The upper contact of layer is abrupt with signs of a break in sedimentation. Thikness is $0.25 \mathrm{~m}$.

PS-3/1. The paleosol occurs with irregular and abrupt contact on the avandeltaic sandstone (sometimes the lower boundary of the paleosol is gradual - fig. 3, C). The profile is composed of light color fine-grained phytoturbated sandstones with the remains of the root systems of horsetails Pinnularia and the lycopsids Stigmaria ficoides (fig. 4, B). The thickness of the paleosol is $0.3 \mathrm{~m}$. The remains of the root systems of horsetails and lycopsids are not found together, but are confined to individual outcrop areas, although sometimes they can be completely absent. This fact may indicate various environmental preferences of these plants.

The paleosols PS-1/1, PS-2/1 and PS-3/1 are most likely to be fluvisols. These soils in the modern geological epoch are formed in river valleys and deltas. They are characterized by stratification inherited from parent sedimentary rocks and poor differentiation into genetic horizons. Usually, only gleying processes are in young fluvisols on the depth more than $25 \mathrm{~cm}$ (Klebanovich, 2015). The features of the paleosols indicate their formation in a humid environment. Nevertheless, O. P. Fisunenko (1987) suggested periods of a short-term increase in climate dryness in the Donets Basin precisely during the accumulation of deposits of the Mospinka Formation.

Layering. The studied rocks have different layering (fig. 2, F; fig. 4, 6). It was used together with other features of the rocks to reconstruct the conditions for the sediments accumulation. Below we focus only on two characteristic texture features of the studied sediments - signs of underwater landslides and thin horizontal lamination.

On the scree of the outcrop 3, pieces of sandstone with textures of creeping and slipping were found. Microfolds are also recorded among the sandstones of layer no. 4 (outcrop 9). Underwater landslides arise due to the action of a factor that violates the equilibrium of the accumulated of nonlithified sediments: the intensive introduction of clastic material as a result of heavy atmospheric precipitation, seismic phenomena, etc. (Dernov, 2013). When assessing the minimum steepness of the slopes at which the sediment begins to move down it, different authors report different values of the degree measure of the angle of inclination of surfaces - from $30^{\prime}$ to $10-15^{\circ}$ (Dernov, 2013). The degree of "mobility" of non-lithified sediments largely depends on its granulometric composition, seismic regime of the territory, climatic features, etc. The sandy composition of rocks composing landslide bodies may indicate a rather significant slope of the basin bottom. At the same time, insignificant volumes of sediments carried down the slope indicate small landslides. 
In fine-grained siltstones of the layer no. 7 (outcrop 6b) a thin lamination is observed, which is represented by the interlayering of brown and light gray siltstone material. Thickness of the layers is $0.5-1.5 \mathrm{~mm}$ and $0.5-1.0 \mathrm{~mm}$, respectively. On average, about 10 thin layers (five pairs) per $10 \mathrm{~mm}$ of thikness. The described lamination can be arbitrarily called seasonal, although the thickness of the interlayers is slightly greater than that of the classic seasonal. In this case, a pair of microlayers form a sequence of precipitation accumulated over one sidereal year. Nevertheless, it is quite possible that the formation of such lamination is associated with rhythmic phenomena of a different nature.

Concretions. In the sandstone stratum, the so-called megaconcretions are observed (Zaritsky, 1959; Makedonov and Zaritsky, 1968). On outcrop 1, they occur in layers no. 2 and 4, on outcrop 2 they occur on the boundary of layers no. 1 and 2, on outcrop 3 they occur in layer no. 2. In the sandstones above $\mathrm{G}_{1}{ }^{2}$, megaconcretions are found only on outcrops 3, 6b and 11 (fig. 3, D; fig. 4, 7). Such megaconcretions are formed at the stage of diagenesis, predominantly early (Zaritsky, 1959; Makedonov and Zaritsky, 1968). The origin of megaconcretions is explained by the processes of infiltration of mixed fresh and marine waters into the sediment, followed by diffusion of iron and calcium ions and their combination with carbon monoxide (Makedonov and Zaritsky, 1968). According to the data by P. V. Zaritsky (1959), these megaconcretions are characteristic for sandy sediments of embankments and bars in the section of Carboniferous of the Donets Basin.

Other types of nodules were also found in sections. At the contact of layers no. $6 \mathrm{a}$ and $6 \mathrm{~b}$, an intermittent interlayer of redeposited siltstone calcareous subspherical nodules of light pink and beige is found. In siltstones of layer no. 3 (outcrop 1), small $(10-30 \mathrm{~mm})$ siderite nodules are observed. As shown in Antoshkina et al., 2017, the formation of siderite nodules is associated with the activity of iron-oxidizing bacteria. Modern siderite nodules are formed in fresh and brackish waters, in which there are more iron ions than calcium ions. According to N. V. Logvinenko (1953), the following conditions are necessary for siderite formation: weakly reducing, up to slightly alkaline, neutral and medium (Ph 7.0-7.2) environmental conditions and local unstable hydrogen sulfide content in sediment. In relation to the studied deposits, the upper boundary of the zone with hydrogen sulfide should have been located, apparently, below the height of the siphon of the infaunal bivalves of the genus Solenomorpha. Siderite nodules in Carboniferous deposits of the Donets Basin are confined to sediments formed in transitional conditions (bays and lagoons) and it is extremely unlikely to find them in marine rocks (Zaritsky, 1959).

In the sandstones of layer no. 2 (outcrop 3), rare nodules of orange ocher and loose limonite are observed due to the oxidation of pyrite. Pyrite crystals are also observed in layer no. 9 (outcrop 1). Pyritization of the rock arose, apparently, due to the excess of hydrogen sulfide in sediments, wich was accumulated due to decomposition of plant tissues.

In siltstones of layer no. 6b siltstone-ocher reddish-yellow nodules of various shapes are observed. Nodules contain fragments of probably siderized phyloids of the lycopsids, which, apparently, were the nuclei around which nodule formation occurred.

Lithoclasts. In the upper part of layer no. 9 (outcrop 1), we met weakly rounded pebbles (up to $4 \mathrm{~cm}$ in size; fig. 2, E) of metamorphic slate. In layer no. 3 of outcrop 2 and on scree of outcrop 3 , accumulations of gravel consisting of metamorphic schists are found. The same pebbles were found in the uppermost part of the sandstones beneath $\mathrm{G}_{1}{ }^{2}$ on outcrop 7. Also found clusters of angularlyrounded pebbles up to $7 \mathrm{~cm}$ in size, consisting of quartz, siderite and limonite nodules, and metamorphic slates.

Many lithologists consider that the Ukrainian Shield and the Priazovian Massif (Logvinenko, 1953) were a sources of clastic material for the Carboniferous terrigenous deposits of the Donets Basin. As in the Bashkirian Age, the research area was separated from the Priazovian Massif by an uncompensated trough with a permanently existing sea basin in it, this option of the demolition area would be incorrect. Therefore, it remains to be assumed that during the accumulation of at least deposits of the Mospinka Formation, the source of clastic material was located on the Ukrainian Shield. 
In sandstones above $\mathrm{G}_{1}{ }^{2}$ (outcrop 8 ), the only small $(2-2.5 \mathrm{~cm}$ ) fragment of greenish-gray and gray-greenish-brown siliceous rock, the origin of which could not be ascertained, was found.

Red-bed deposits. On outcrop 1, as already noted above, siltstones are found that can be diagnosed as red-bed rocks (layers no. 6a, 6c and 6d; fig. 4, 12). According to A. P. Feofilova (1966), in the Upper Pennsylvanian of the Donets Basin, red-bed rocks are confined to the most shallow water lacustrine sediments. This conclusion is indirectly consistent with our observations, according to which layers no. $6 \mathrm{~b}-6 \mathrm{c}$ were formed, most likely, in the conditions of a shallow water desalinated lagoon. According to the observations of A. P. Feofilova (1966) on the red-bed deposits, the Late Pennsylvanian climate of the Donets Basin was variable-humid with gradually increasing aridity. The transition from graycolored lagoonal sediments (layer no. 6b) to red-bedded lagoonal deposits (layer no. 6c) is gradual. Therefore, the change of sedimentation conditions was quite smooth and was associated with the moment of short-term climate aridization. This observation agrees well with the xeromorphic habitus of pteridosperms of the genus Lyginopteris, whose rachises remains are frequent in layer no. 6.

Layer no. 6a is the remains of the lowest part of the paleosol, not destroyed by waters of the lagoon. As noted above, O. P. Fisunenko (1987) suggested that periods of short-term aridity of the climate were characteristic of the time of accumulation of sediments of the Mospinka Formation. In literature sources, red-bed rocks in the Donets Basin were not noted among sediments older than the Mospinka Formation (Logvinenko, 1953).

Coals. In the sandstones above limestone $\mathrm{G}_{1}{ }^{2}$, there is a layer enriched with carbonaceous matter (layer no. 8a, outcrop 11). On outcrop 6b, this carbonaceous layer corresponds to a thin coal bed $\mathrm{g}_{1}{ }^{1}$. It seems that the accumulation of peat, which subsequently gave rise to this coal layer, occurred on numerous delta islands. Thus, the coal layer is intermittently distributed and it disappears at a distance of $3 \mathrm{~km}$ from the place of its observation. The coal interbed $\mathrm{g}_{1}{ }^{2}$, which lies in the roof of the mentioned sandstones, is closely connected with lagoonal-lacustrine deposits that underlie and overlap it.

\section{Paleontological features of sediments}

Microbial mats. On many studied outcrops, we noted sedimentary textures that are interpreted as traces of the impact of microbial mats on sediment. In the most comprehensive review of such textures (Schieber et al., 2007), many of their morphological types were described, some of which were also found in the studied sandstone strata. Among them: "microbial sand chips", microbial mats with erosion marks, worm-shaped folds, cracks on the corrugated surface of a wave ripple, "Kinneyia-type" textures, "sand cracks", "algal balls" or "sand balls", textures of the type "Manchuriophycus" and others. In addition, disk-shaped microbial colonies and small limonitized fragments of microbial films were also observed. The last, apparently, were destroyed by water dynamics and subsequently buried. All morphological types noted below are typical usually for coastal sediments (Schieber et al., 2007).

Terrestrial plants. Studied deposits abound with the remains of terrestrial plants (fig. 4, 4-5, 8-10; fig. 5, 6, 7), which, however, are often represented by indefinable fragments. The systematic composition of phytocomplexes is presented in Table 1.

The remains usually are represented by prints and ebbs of the internal cavities of trunks. Sometimes they are covered with a crust of limonite formed due to the oxidation of pyrite. In nodules from layer no. $6 \mathrm{~b}$ (outcrop 1), the remains of Cyperites bicarinatus Lindley et Hutton are found, which are probably replaced by siderite. The dominance of phyloids in the composition of phytoorictocenosis from layer no. $6 \mathrm{~b}$ is notable. This may be due to the entry into the sediments of the inner part of the lagoon of the lightest and capable to transporting organs of plants.

In layer no. 1 (outcrop 2), in one of the megaconcretion, an accumulation of differently oriented fragments of horsetails axes and their roots was found. To the west and to the east this accumulation is rapidly depleted. The study of megaconcretion showed that the accumulation of phytophossils is confined to a layer of layered sandstone, through which megaconcretion developed during 
diagenesis. It is this circumstance that explains the presence of plant debris only in the upper half of megaconcretion. Thus, the formation of megaconcretions is not associated with the accumulation of phytofossils. In medium-coarse-grained, non-layered sandstones, exposed to the west of outcrop 5 and corresponding to layer no. 12 of outcrop 11, fragments of limonitized cores of cordaitanth trunks (Artisia approximata) are found. These remains form a thin layer in the sandstones.

According to the classification by O. P. Fisunenko (1973), phytoorictocenoses of the studied deposits can be attributed to the autochthonous (for example, remains of lycopsids roots buried in situ in layer no. 5 outcrop 1, etc.) and the allochthonous type (almost all studied plant burials). The hypoautochthonous type of phytoorictocenoses has not been established.

\section{Table 1. The systematic composition of complexes of plant remains from the studied sandstones Таблиия 1. Систематичний склад комплексу решток рослин з вивчених пісковиків}

\begin{tabular}{|c|c|}
\hline Outcrops & Plants \\
\hline 1 & $\begin{array}{l}\text { Cyperites bicarinatus Lindley et Hutton, Knorria sp., Lepidodendron aculeatum Sternb., L. cf. obovatum } \\
\text { (Sternb.), Lepidodendron sp., Lepidophloios laricinus (Sternb.) Gold., Lepidophloios sp., Sigillaria sp., Stigmaria } \\
\text { ficoides (Sternb.) Brongn., Stigmaria rugulosa Gothan, Stigmaria sp., Asterophyllites charaeformis (Sternberg) } \\
\text { Goeppert, Asterophyllites sp., Calamites cistii Brongniart, Calamites schutzeiformis Kidst. et Jongm., Calamites } \\
\text { suckowii Brongn., Calamites sp., Sphenophyllum sp., Dictyoxylon sp., Karinopteris sp., Neuralethopteris sp., } \\
\text { Paripteris gigantea (Sternb.) Gothan, Artisia approximata (Lindley and Hutton) Corda, Cordaites sp., Carpo- } \\
\text { lithes sp., Samaropsis sp. }\end{array}$ \\
\hline 2 & $\begin{array}{l}\text { Cyperites bicarinatus Lindley et Hutton, Lepidodendron obovatum Sternb., Sigillaria sp., Calamites cistii } \\
\text { Brongn., Calamites schutzeiformis Kidst. et Jongm., Pinnularia capillacea Lindley et Hutton, Artisia approxi- } \\
\text { mata (Lindley and Hutton) Corda, Cordaites sp., indeterminate pteridosperms. }\end{array}$ \\
\hline 3 & $\begin{array}{l}\text { Stigmaria ficoides (Sternb.) Brongn., Calamites sp., Pinnularia sp., Pachytesta sp., Trigonocarpus sp., Arti- } \\
\text { sia approximata (Lindley and Hutton) Corda, Cordaicladus sp., Cordaites sp., Samaropsis sp., fragments of } \\
\text { pteridosperm rachis. }\end{array}$ \\
\hline $6 \mathrm{~b}$ & $\begin{array}{l}\text { Bothrodendron sp., Cyperites bicarinatus Lindley et Hutton, Lepidophloios laricinus (Sternb.) Gold., Sigillaria } \\
\text { sp., Stigmaria ficoides (Sternb.) Brongn., Asterophyllites grandis (Sternb.) Geinitz, Calamites cisti Brongn., Ca- } \\
\text { lamites schutzeiformis Kidst. et Jongm., Calamites sp., Sphenophyllum sp., Alethopteris sp., Eusphenopteris sp., } \\
\text { Karinopteris sp., Paripteris gigantea (Sternb.) Gothan, Cordaites sp. }\end{array}$ \\
\hline 8 & Sigillaria tesselata Brongn., Stigmaria ficoides (Sternb.) Brongn., Calamites schutzeiformis Kidst. et Jongm. \\
\hline 9 & Stigmaria ficoides (Sternb.) Brongn., Sigillaria sp. \\
\hline 11 & Appendixes of Stigmaria, Calamites sp. \\
\hline
\end{tabular}

Fig. 4. Details of the structure of the section of the studied sandstones: 1, 2 - rhizolites (layer no. 5, outcrop 1): 1 - the surface of the sandstone layer with numerous rhizolites, 2 - the longitudinal cleavage of the rhizolite; 3 - multi-colored weakly cemented sandstones on outcrop 1; 4 - lycopsid root Stigmaria ficoides (Sternb.) Brongn., buried in situ (layer no. 5, outcrop 1); 5 - sandstone megaconcretion with remains of the horsetails axes Calamites sp. (border of layers no. 1 and no. 2, outcrop 2); 6 - cross-bedded lamination of sandstones of layer no. 6 (outcrop 6b); 7 - megaconcretion with abundant plant remains in the upper part and an unidentified crack at the base (layer no. 1, outcrop 2); 8 - accumulation of surf-oriented plant debris in layer no. 2, outcrop 3 (the place of find of the insect wing fragment shown in fig. 5, 4; the arrow points to the north); 9 - accumulation of large plant detritus on the surface of sandstone (layer no. 2, outcrop 3); $10-$ remains of plant Cordaicladus sp. (outcrop 3); 11 - erosion marks at the base of the layer of megaconcretions (layer no. 1, outcrop 2); 12 - red-bed siltstones (layer no. 6, outcrop 1). The scale bar/line is $20 \mathrm{~mm}(1 \mathrm{and} 2), 50 \mathrm{~mm}$ (3 and 4), $100 \mathrm{~mm}(6-9,11,12)$, and $30 \mathrm{~mm}(10)$.

Рис. 4. Деталі будови розрізів вивчених пісковиків: $1,2-$ ризоліти (шар № 5, відслонення 1): $1-$ поверхня шару пісковику з численними ризолітами, 2 - повздовжній скол ризоліту; 3 - строкатоколірні слабко зцементовані пісковики на відслоненні № 1; 4 - ризофори Stigmaria ficoides (Sternb.) Brongn., що поховані in situ (шар № 5, відслонення 1); 5 - пісковикова мегаконкреція 3 рештками осей хвощеподібних Calamites sp. (межа шарів № 1 та № 2, відслонення 2); 6 - коса шаруватість пісковиків шару № 6 (відслонення 6b); 7 - мегаконкреція з рештками рослин у верхній частині та тріщиною нез'ясованої природи в основі (шар № 1, відслонення 2); 8 - скупчення орієнтованого прибоєм рослинного детриту в шарі № 2, відслонення 3 (місце знахідки фрагменту крила комахи, зображеного на рис. 6,8 ; стрілка вказує на північ); $9-$ скупчення крупного рослинного детриту на поверхні пісковику (шар № 2, відслонення 3); 10 - рештки рослини Cordaicladus sp. (відслонення 3); 11 - сліди розмиву в нижній частині шару з мегаконкреціями (шар № 1, відслонення 2); 12 - червоноколірні алевроліти (шар № 6, відслонення 1). Довжина масштабної шкали/відрізку для фіг. 1 та $2-20$ мм, фіг. 3, 4-50 мм, фіг. 6-9, 11, 12 - 100 мм, фіг. $10-30$ мм. 


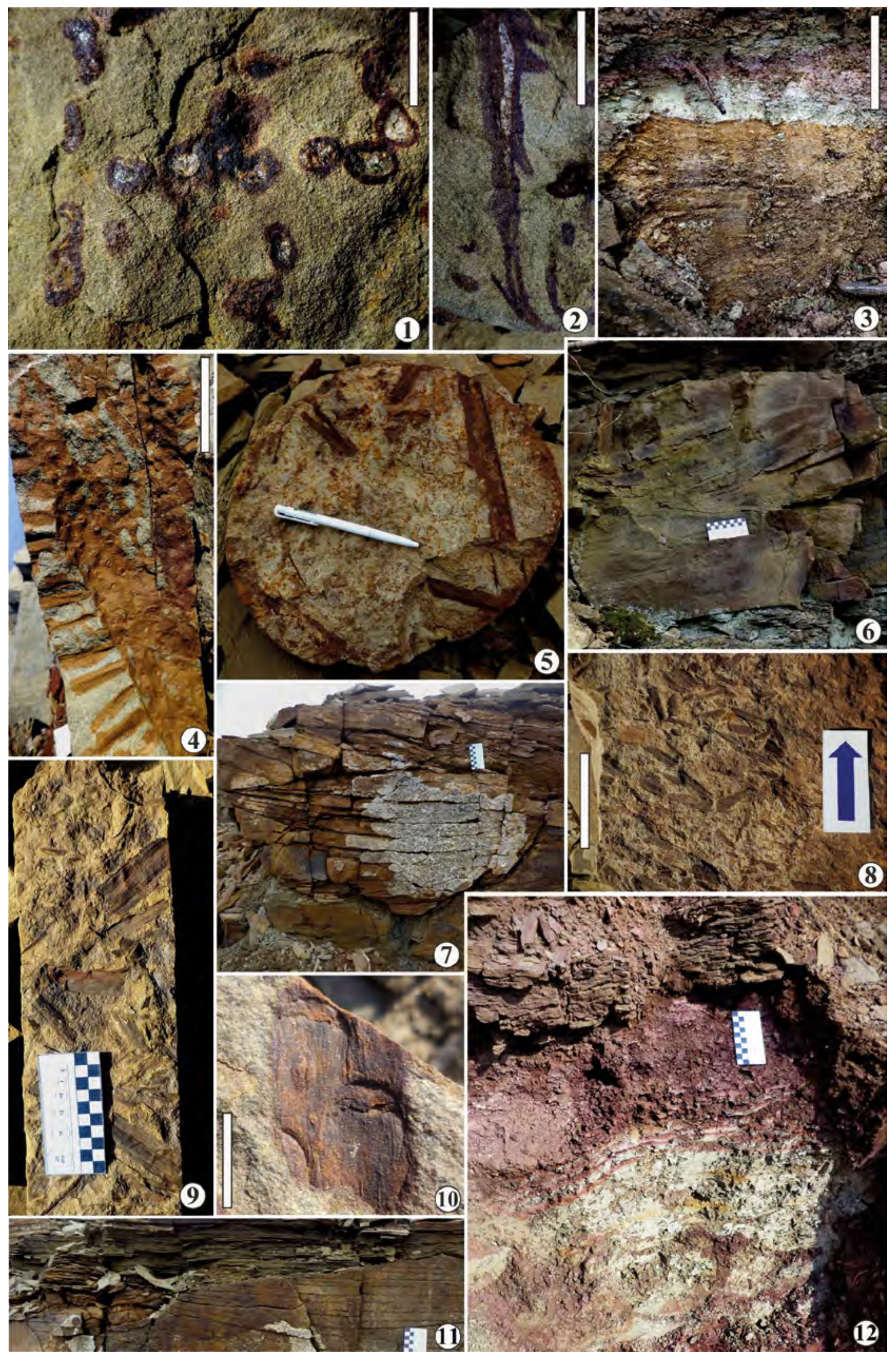



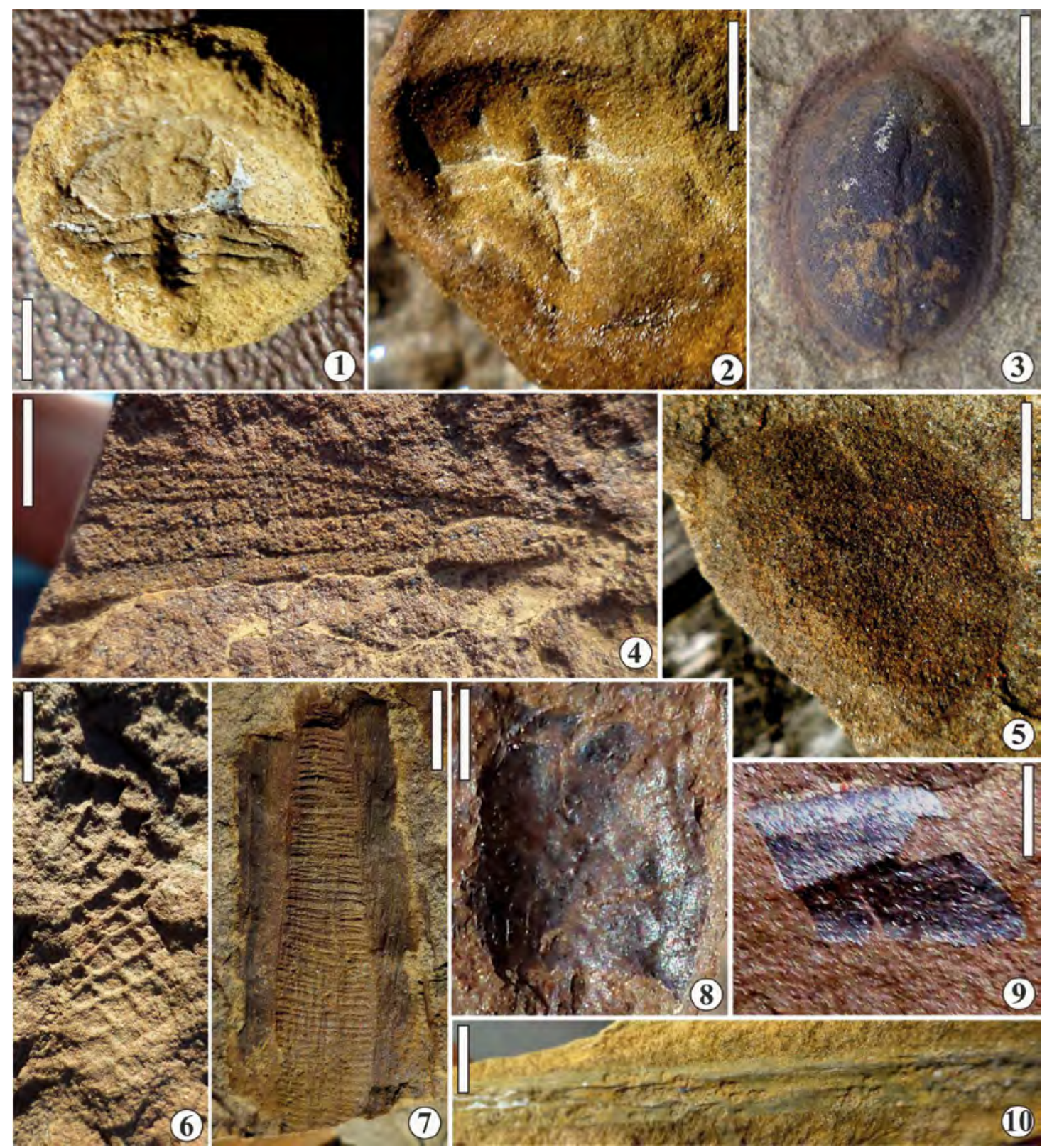

Fig. 5. Remains of animals, plants and trace fossils from the studied sandstones: 1,2- remains of horseshoe crabs (layer no. 6b, outcrop 1; samples no. 6902 and 4340); 3 - Pachytesta sp. (outcrop 3, scree, field photo); 4 - imprint of the wing of the Paleodictyoptera (outcrop 3, layer no. 2); 5 - supposed remains of jellyfish (outcrop 1, layer no. 9; sample no. 3727); 6 - imprint of the axis of Lepidophloios sp. (outcrop 1, layer no. 9; field photo); 7 - Artisia approximata (Lindley and Hutton) Corda (outcrop 3, layer no. 2; field photo); 8 - remains of a crustacean of the family Pygocephalidae (outcrop 1, layer no. 6c); 9 - isolated scale of Actinopterygii (outcrop 1, layer no. 6c); 10 - remains of the phyloid Cyperites bicarinatus with galls on the surface (outcrop 1, layer no. 6b; field photo). The scale bar is $10 \mathrm{~mm}$ (1-7 and 10), $2 \mathrm{~mm}(8), 3 \mathrm{~mm}(9)$.

Рис. 5. Рештки тварин, рослин та іхнофосилії з вивчених пісковиків: 1,2 - рештки мечохвостів (шар № 6b, відслонення 1; зразки № 6902 та 4340); 3 - Pachytesta sp. (відслонення 3, осип, польове фото); 4 - відбиток крила палеодиктіоптери (шар № 2, відслонення 3); 5 - здогадно рештки медузи (шар № 9, відслонення 1; зразок № 3727); 6 - відбиток осі Lepidophloios sp. (відслонення 1, шар № 9; польове фото); 7 - Artisia approximata (Lindley and Hutton) Corda (відслонення 3, шар № 2; польове фото); 8 - рештки ракоподібного родини Pygocephalidae (відслонення 1, шар № 6c); 9 - ізольована луска кісткової риби (відслонення 1, шар № 6c); 10 - рештки філоїду Cyperites bicarinatus з галлами на поверхні (відслонення 1, шар № 6b; польове фото). Масштабний відрізок для фіг. 1-7 та 10-10 мм, для фіг. $8-2$ мм, для фіг. $9-3$ мм. 
The remains of plants found in layers no. 7 and no. 9 (outcrop 1) and no. 2 (outcrop 3) are often oriented by the surf. We measured the spatial orientation of elongated remains (trunks and branches). In layer no. 7, the prevailing number of phytophossils (a total of 38 plant remains from this layer was measured) are oriented parallel to the SW-NE (60\%) and E-W directions (about 30\% of measurements). The 35 measurements in layer no. 9 showed that phytophossils are located mainly parallel to the direction of NW-SE (approximately $48 \%$ ) and W-E (26\%).

In layer no. 2 (outcrop 2), plant detritus is oriented mainly parallel to the north-south direction. In the sandstones of layer no. 2 (outcrop 3), detritus is oriented mainly parallel to the directions E-W and NW-SE. Based on this, we can assume that during the formation of layer no. 7 (outcrop 1), the coastline of the basin passed approximately in the SW-NE/E-W direction relative to the modern outcrop. During the formation of layer no. 9 (outcrop 1) the coastline passed parallel to the direction of NW-SE/E-W. Apparently, the coastline had approximately the close strike during the formation of sandstones above the $\mathrm{G}_{1}{ }^{2}$. This conclusion is also confirmed by the fact that in the south-southeast direction coal-bearing deposits of the Mospinka Formation are replaced by deepwater sediments of the Dyakovska Series.

The landscapes A and B by O. P. Fisunenko (1987) were predominantly developed in the area of accumulation of deltaic sediments. The first of them is heavily flooded coastal lowland, characterized by the development of monotaxon associations of semi-aquatic plants (Calamites). The second landscape is partially flooded coastal lowland characterized by the widespread development of freshwater lakes and mosaic phytocenoses with dominant lycopsids and Calamites.

The data obtained allow us to clarify the vertical distribution of certain plant taxa in the Carboniferous deposits of the Donets Basin. For example, representatives of the genus Pinnularia, according to E. O. Novik (1952), appear in the roof of the coal bed $\mathrm{g}_{2}$ (upper part of the Mospinka Formation). Although we have noted them somewhat lower. The same applies to the rhizophore Stigmaria rugulosa Gothan, which we recorded in layer no. 9 (outcrop 1), although, according to E. O. Novik (1952), they appear in the Donets Basin only in the upper part of the Mospinka Formation (at the bottom of the coal seam $\mathrm{g}_{3}$ ). Branches of cordaitanth Cordaicladus (fig. 4, 10) were not mentioned earlier in the literature for the Carboniferous flora of the Donets Basin. The isolated phyloids of the lycopsids Cyperites bicarinatus Lindley et Hutton in the Donets Basin were previously mentioned under other names (for example, Lepidophyllum, "leaves of Lepidodendron", etc.). Noteworthy are the frequent finds of large isolated pteridosperm seeds Pachytesta on outcrops 1 (layers no. 7 and 9) and 2 (layer no. 3) (fig. 5, 3), which previously, as far as we know, were not pointed in the Carboniferous deposits of Donets Basin.

Molluscs. On the outcrop 1, two sharply ecologically distinct communities of bivalves were found: marine, consisting of Solenomorpha sp. (layer no. 3) and freshwater (layer no. 6b), including representatives of the genus Carbonicola McCoy, 1855. Remains of non-marine pelecypods were also found in layer no. $6 \mathrm{c}$, but they could not be determined. It should be noted that the remains of bivalves of both of these genera were found in nodules in the form of internal moulds and shells with tightly closed valves, which, presumably indicates a low dynamics of bottom waters. B. I. Chernyshev (1931) identified a group of non-marine bivalves consisting of Carbonicola, Naiadites and Anthracomya (=?Anthraconaia, Curvirimula, Abakaniella and some Permian genera (Neveskaya et al., 2013) called the "Carbonicola facies," which, in his opinion, was inherent in the shallow water of desalinated seas. Later P. L. Shulga (1948) showed that it is a special biofacia inherent in fresh waters inhabited by bivalves Carbonicola and ecologicaly related genera.

According to M. T. Sergeeva (1969), Carboniferous non-marine mollusks of the Donets Basin existed in two main biotopes: closed reservoirs such as sapropel lakes with a muddy bottom and complicated aeration (mainly Anthraconauta) and desalinated lagoons and bays with denser bottom sediments and sufficient of oxygen at the bottom (Carbonicola, Anthraconaia and Naiadites). In our opinion, siltstones of layers no. $6 b-6 c$ were formed in small desalinated lagoons. Presumably, the 
remains of freshwater and brackish-water bivalves discovered by us are the oldest in the section of the so-called “Open Donbas”. According to M. T. Sergeeva (1969), non-marine bivalves are often found starting from the coal layer $\mathrm{g}_{3}$ (upper part of the Mospinka Formation).

Bivalves of the genus Solenomorpha led a burrowing lifestyle and, according to our observations at other localities of the Pennsylvanian fauna, preferred water areas with clayey silts and moderate depths.

Unindefied remains of marine bivalves were also found in the megaconcretion with mass horsetails imprints at the contact of layers no. 1 and 2 (outcrop 2). Rare imprints of shells of marine pelecypods Palaeoneilo sp. and some other were found on the scree of outcrop 3. According to the work (Neveskaya et al., 2013), the genus Anthraconeilo Girty, 1911 is the younger synonym for the genus Palaeoneilo Hall et Whitfield, 1869. Therefore, all Donetsk species (about 11-16 according to Aisenverg et al., 1963) previously attributed to the first taxon, now, apparently, should be included to the second. Note that the famous malacologists B. I. Chernyshev, D. M. Fedotov and P. L. Shulga recognized the independence of both of these genera.

The genus Palaeoneilo in the Carboniferous water areas of the present Donets Basin inhabited within the so-called "zone with Phestia" - a section of the marine basin with clayey, sandy clayey, carbonate silts, moderate and low water activity (Sergeeva, 1969). Based on our own observations on the paleoecology of the marine Carboniferous fauna of the Donets Basin, we can add that representatives of the genus Palaeoneilo (=Anthraconeilo) often dominate in associations of bivalves found among mudstone. We also note that in mudstones where bivalves Palaeoneilo are frequent, representatives of Phestia are extremely rare. In siltstones, the frequency of occurrence of both genera is approximately the same. Thus, it seems that the genus Palaeoneilo in the Pennsylvanian sediments of the Donets Basin were distributed in rather shallow water zones with a sandy bottom and high hydrodynamics of waters, as well as relatively deep-water ones with complicated aeration and clayey silts. In the sandstones above $\mathrm{G}_{1}{ }^{2}$ (outcrop 11, layer no. 10), limonite nodules contain shells imprints of the bivalves Sanguinolites sp., which are buried with closed valves. According to our observations, these bivalves selected relatively deep-water areas of water with clayey silts for their habitation. Although in the case of the mentioned deposits, they apparently characterize relatively shallow water deposits.

In the concretion from siltstones of layer no. 3 (outcrop 1), one Belerophontida shell was found. According to our observations on the fossil fauna of the Pennsylvanian deposits of the Donets Basin, the belerophontids did not have strict facies confinement and lived in zones of sedimentation of calcareous, clay, silty, and sandy sediments. It should be noted that in some limestones and sandstones the dimensions of the shells of belerophontids reach comparatively large sizes for the Lower Pennsylvanian of the Donets Basin (up to $30 \mathrm{~mm}$ and more). This circumstance may indicate favorable conditions for their residence, prevailing in places of deposition of sands and calcareous silts. Nevertheless, in mudstones and siltstones, the number of shells of these mollusks is noticeably larger than in limestones and especially sandstones, but their sizes are relatively small. Summarizing all of the above, we can assume that the Pennsylvanian belerophontids, obviously, were an ecologically strongly differentiated group and led bentic and planktonic way of life. Presumably, they were able to withstand minor fluctuations in water salinity.

Arthropods. In layer no. 6b (outcrop 1), remains of small horseshoe crabs (Euproops sp. and some unidentified) were found. (fig. 5, 1, 2). In layer no. 9 of the same outcrop, both allochthonous skeletal remains are found (fig. 7, 5), as well as trace fossils of large indetermined horseshoe crabs (fig. 7, 3; fig. 8, 1, 3, 8). According to E. S. Shpinyov (2018), in the Pennsylvanian location "KamenskShakhtinsky 1" (eastern part of the Donets Basin), the remains of Euproops found in deposits were formed under conditions of "landscape D" by O. P. Fisunenko (weakly dissected, slightly hilly plain with predominance of pteridosperms in phytocenoses (1987). Siltstones of layer no. 6b, in which the remains we studied were found, were formed under distinctly different conditions than "landscape D”. This testifies to the assumption of E. S. Shpinyov (2018) about significant environmental plastic 
horseshoe crabs Euproops. Our findings show that large individuals of Carboniferous horseshoe crabs seem to gravitate to sublittoral and supralittoral marine environments, while small ones to desalinated and freshwater basins.

Supposed arthropod remains are also found in flattened limonite nodules among siltstones of layer no. 6 b (outcrop 1) and in sandstones of layer no. 7 of the same outcrop. In the first case, we are possibly dealing with a crustacean arthropod from the family Pygocephalidae (fig. 5, 8). In addition, unidentified arthropod remains are known from other parts of the studided outcrops (fig. 7, 8-11).

In layer no. 9 (outcrop 1), the remains of arthropods are mainly represented by imrprints, in which fragments of carbonized chitin are observed in some places. In layer no. 2 (outcrop 3), no traces of chitin were found in the fossils. All remains are allochthonous and, to varying degrees, rounded by the surf, especially those on outcrop 1 . The remains of horseshoe crabs found in layer no. $6 \mathrm{~b}$ are represented by imrprints. Based on the quality of preservation, they were not significantly transported and they were quickly buried after the death of the animal.

The remains of arthropods Arthropleura sp. were found in layer no. 9 (outcrop 1), layer no. 2 (outcrop 2) and layer no. 2 (outcrop 3). (fig. 6; fig. 7, 7). Due to the fact that arthropleurid remains are buried in relatively coarse sediments, the fine details of their morphology usually have not been preserved. That is why interpretation of many fossils is complicated. In this regard, we note that the collection has many undefined remains, apparently belonging to Arthropleura and large horseshoe crabs. Currently, we have managed to identify among them only a few, in our opinion, belonging to Arthropleura, namely: the imprint of the dorsal shield (fig. 6, 6), the remains of the K-plate (fig. 6, 8), the remains presumably paratergitis and sintergitis (fig. 6, 10) and remains of the B-element. All of the these fossils we define as Arthropleura sp. Based on the proportions of the size of the K-plate (sample no. 3736, fig. 6, 8), limbs and body length of Arthropleurids, it can be concluded that the body length of the individual animal to which it belonged was about $1.3 \mathrm{~m}$.

Arthropods of the genus Arhropleura Jordan, 1854 have long attracted the attention of paleontologists (Schneider, Werneburg, 2010). This fact is not surprising because these animals are the largest terrestrial invertebrates in the history of Earth (the reconstructed length of some individuals was about $2.5 \mathrm{~m}$ (Schneider, Werneburg, 2010). Despite the considerable popularity of these animals among a wide audience, a long history of research, and a non-decreasing interest of paleontologists towards these arthropods, nevertheless, in many respects they are still rather mysterious creatures.

Various publications have been devoted to several questions of morphology and ecology of this arthropod (Andrée, 1910; Castro, 1997; Copeland, 1957; Schneider et al., 2010; Schneider, Werneburg, 2010 , etc.). Nevertheless, new findings of the remains of this animal are of undoubted interest, because their study allows to approach the solution of both particular issues of paleoecology and taphonomy, and to carry out large-scale paleobiogeographic generalizations.

The remains of arthropods of the genus Arhropleura are known in the fossil record from the upper part of the Viséan Stage (Mississippian) to the Asselian Stage (Cisuralian) of the paleotropic belt of Euramerica (Schneider and Werneburg, 2010).

Regarding the position of the genus Arhropleura Jordan, 1854 in the system of arthropods, the opinions of researchers differ. For example, some experts attributed them to arachnids, while others considered it possible to distinguish them into a special class (Novozhylov, 1962). Studies by Komarek (Novozhylov, 1962) allowed bringing arthropleurids closer to Diplopoda. In some works devoted to these arthropods (Schneider, Werneburg, 2010), the authors, when indicating the systematic affiliation of arthropleurids, are content with the word "arthropods", thereby showing the ambiguity of their position.

There are many views on the issue of arthropleurids diet. According to some of them, arthropleurids were palynophages (Schneider, Werneburg, 2010) or xylophages, i.e. fed on the wood of the giant lycopsids (Shear, Kukalová-Peck, 1990). There is an alternative point of view, according to which fructification, megasporophylls and large seeds could be their food (Schneider, Werneburg, 2010). 
The main drawback of this point of view is the seasonal nature of the availability of this food, since, starting from the second half of the Moscovian Age, the climate of Euramerica felt an increase in seasonality. This factor determines the frequency of ripening of fructifications and seeds (Schneider, Werneburg, 2010). Thus, the problem of diet of Arthropleura is completely unresolved. Moreover, detritophagy (Yeskov, 2008) and predatory lifestyle of these arthropods are not denied (Shear, KukalováPeck, 1990).

Another interesting question is the cause of gigantism of Arthropleura. According to some views (Yeskov, 2008), the relatively large size of Late Paleozoic terrestrial arthropods (for example, Arthropleura and insects of the genus Meganeura with a wingspan of up to $1 \mathrm{~m}$ ) are due to the increased oxygen content in the then atmosphere. For this reason, the length of the tracheal tubes that allow respiration in terrestrial arthropods was increased. Of course, in this case, the overall dimensions of the animal's body should be enlarged or even gigantic (Yeskov, 2008). The second point of view considers gigantism of Arthropleura as a manifestation of the Cope's-Depere's rule, according to which the significant dimensions of Arthropleura are a kind of "response" of these arthropods to amphibians and reptiles, which were their competitors for food resources (Schneider, Werneburg, 2010). A. G. Sharov (1973) explained the large sizes of other giants of Carboniferous - dragonflies of the order Meganizoptera - by the significant dimensions of their prey, namely the Paleodictyoptera. Nevertheless, the issue of gigantism of the representatives of Paleodictyoptera themselves is unclear (the wingspan of some species reached $40 \mathrm{~cm}$ ).

In addition to the body remains of Arthropleura, traces of their locomotion are also well studied, which were called Diplichnites cuithensis Briggs, Rolfe et Brannan, 1979 (tracks up to $38 \mathrm{~cm}$ wide, belonging to adult animals) and Diplichnites minimus Walter et Gaitzsch, 1988 (tracks left by juvenile individuals) (Briggs et al., 1979; Schneider et al., 2010). Nevertheless, the second ichnospecies is apparently a subjective synonym for the first (Getty et al., 2017). These trace fossil are known from the Upper Viséan - Asselian deposits of the USA, Canada, Scotland, Germany, and France (Schneider et al., 2010; Whyte, 2018).

There is evidence for the presence of traces of Arthropleura locomotion in the Pennsylvanian sediments of the Zhezkazgan depression (Kazakhstan) (Nelikhov, 2010). Here, P. K. Chudinov in 1958, among the deposits of the Zhezkazgan Series, studied numerous traces of the locomotion of "labyrinthodonts and pelicosaurs" (Esenov, Shlygin, 1972). These tracks are confined to the lower surface of the layer of hard, apparently deltaic sandstones. In Gubin et al., 2003, it is assumed that some of the tracks from Zhezkazgan belong to Parabaropus isp. Together with the tetrapod tracks, one track of Arthropleura (2.5 m long with a width of $12-13 \mathrm{~cm}$ ) was discovered (Nelikhov, 2010).

Fig. 6. Remains of arthropods from sandstones (outcrop 1-3): 1-5 - remains of arthropod Arthropleura sp. (layer no. 9, outcrop 1; 1, 3-5 - field photo, 2 - fragment of phototable XXV from the monograph by Pruvost, 1919; 6, 7 - remains of the dorsal plate of arthropod Arthropleura sp.: 6 - from layer no. 9 (outcrop 1; sample no. 3778), 7 - photo from Schneider, Werneburg, 2010, fossil from the Cisuralian of Thuringia; 8 - remains of the K-plate of the arthropod Arthropleura sp. (layer no. 9, outcrop 1; no. 3736); 9 - undetermined remains of arthropods from layer no. 9 (outcrop 1; field photo); 10 - presumed remains of sintergite of the arthropod Arthropleura sp. (layer no. 9, outcrop 1; no. 4928); 11 - remains of integument of arthropod Arthropleura sp. (outcrop 3, scree; sample no. 6732); 12 - ?Arthropleura sp. (layer no. 2, outcrop 2; sample no. 7854). The scale bar is $10 \mathrm{~mm}(1,4,5,8,10,12), 5 \mathrm{~mm}(3), 20 \mathrm{~mm}(9)$.

Рис. 6. Рештки членистоногих з пісковиків (відслонення 1-3): 1-5 - рештки членистоногих Arthropleura sp. (шар № 9, відслонення 1; 1, 3-5 - польове фото, 2 - фрагмент фототаблиці XXV з роботи (Pruvost, 1919); 6, 7 - рештки дорсальної пластинки членистоного Arthropleura sp.: 6 - 3 шару № 9 (відслонення 1; зразок № 3778), 7 - фото з роботи (Schneider, Werneburg, 2010), фосилія з нижньої пермі Тюрингії; 8 - рештки К-пластинки артроподи Arthropleura sp. (шар № 9, відслонення 1; зразок № 3736); 9 невизначені рештки артропод 3 шару № 9 (відслонення 1; польове фото); 10 - здогадно рештки синтергіту артроподи Arthropleura sp. (шар № 9, відслонення 1; зразок 4928); 11 - рештки покривів членистоногого Arthropleura sp. (відслонення 3, осип; зразок № 6732); 12 - ?Arthropleura sp. (шар № 2, відслонення 2; зразок № 7854). Масштабний відрізок для фіг. 1, 4 5, 8, 10, $12-10$ мм, для фіг. $3-5$ мм і для фіг. $9-20$ мм. 


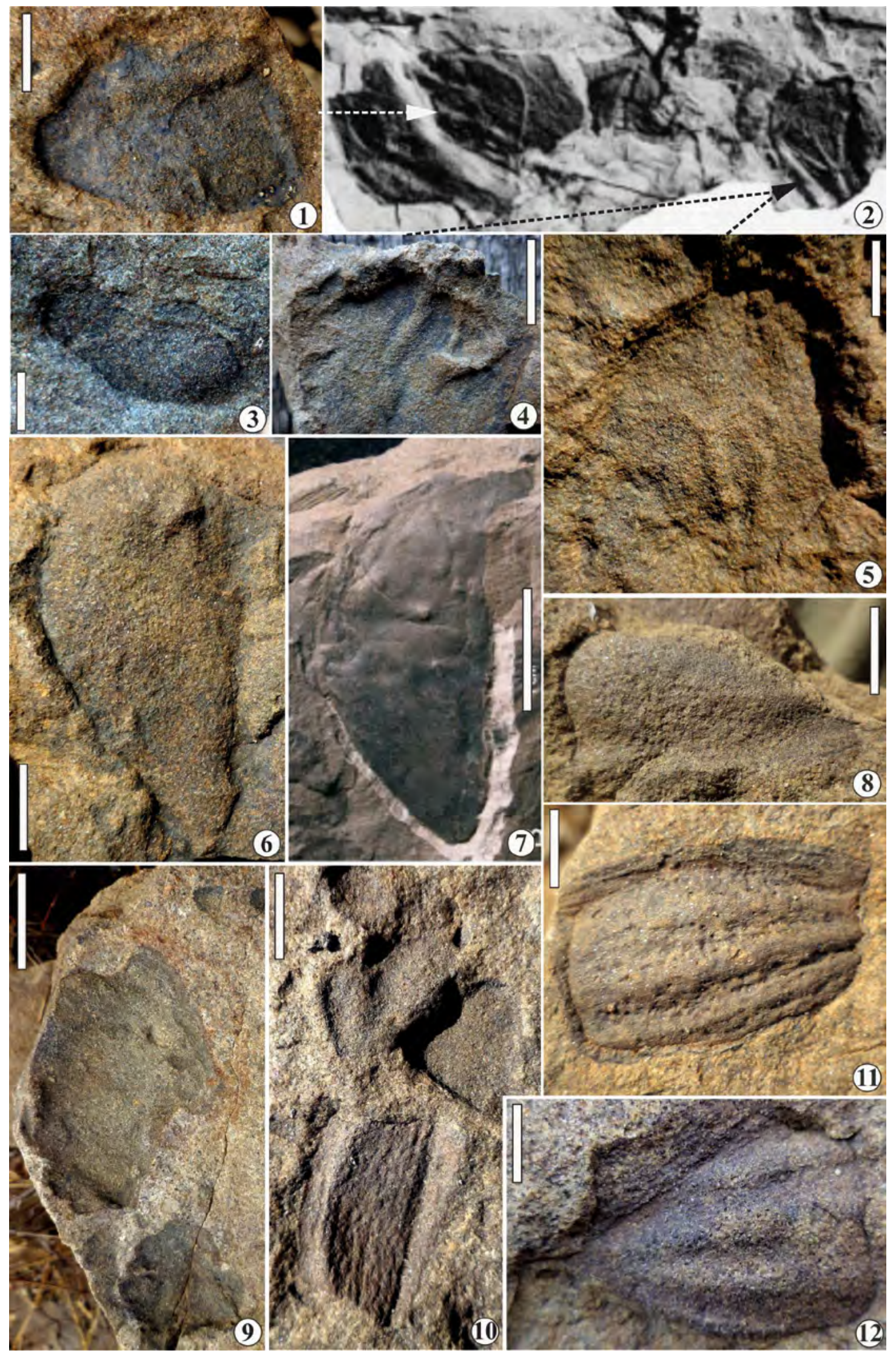




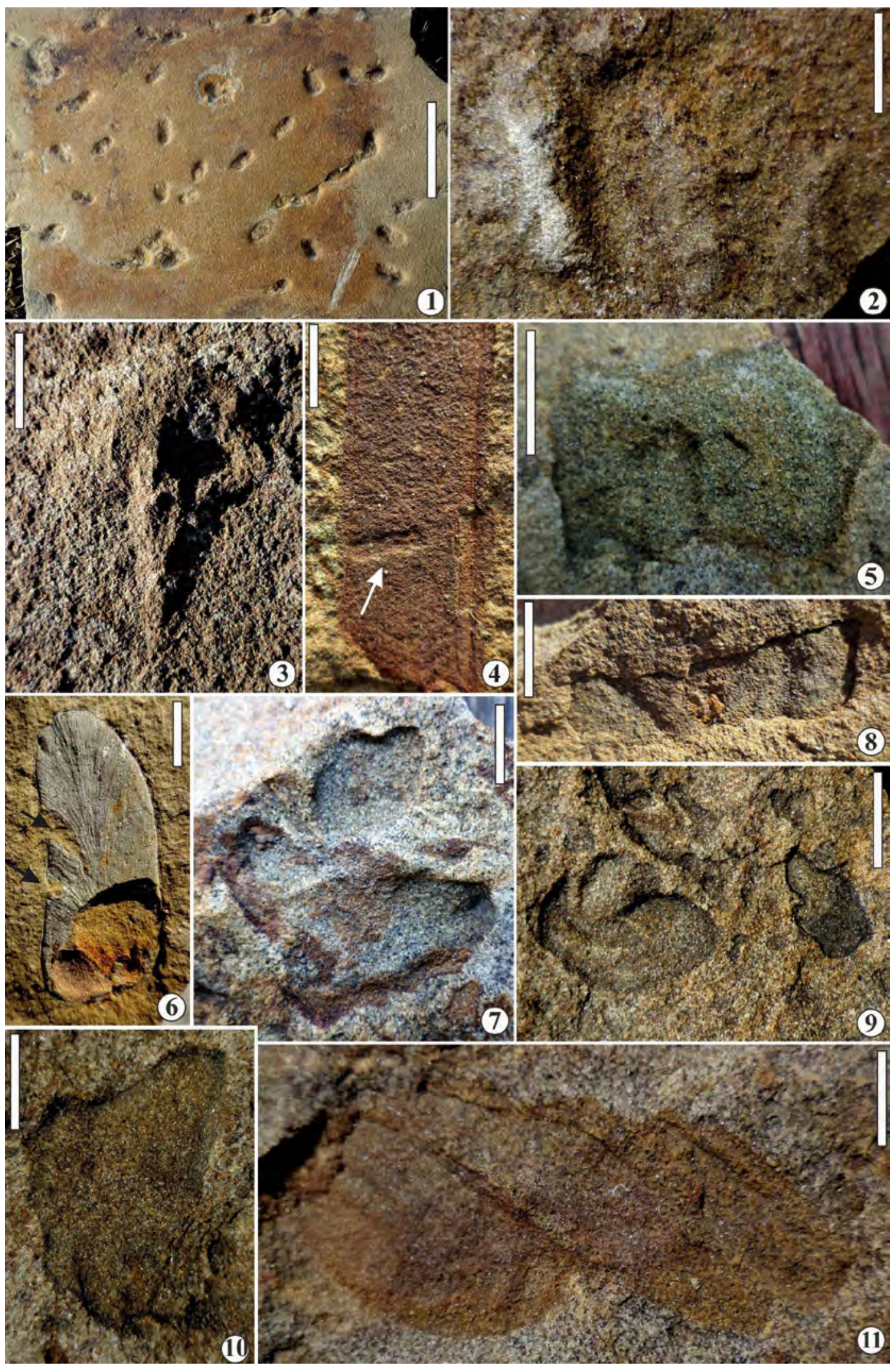


Based on the information on their morphology, this trace fossil should be attributed to Diplichnites cuithensis. The red-bed sediments of the Zhezkazgan Group represented by sandstones, siltstones, mudstones and pelitomorphic limestones were formed mainly in deltaic, lakustrine and floodplain conditions, as well as in conditions of coastal plain and epicontinental sea (Esenov, Shlygin, 1972). Currently, Zhezkazganian traces are the most northern (in relation to the ancient coordinate grid) finds to evidence the presence of Arthropleura. According to Schneider, Werneburg, 2010, the modern Zhezkazgan depression in the Carboniferous and Permian was located in the arid zone.

We focused on the Zhezkazganian finds in detail, since this trace fossil is unknown to the scientific community, because scanty information about this unique find was presented only in a brief historical sketch by A. Nelikhov (2010). Note that the "Fundamentals of Paleontology" (Novozhylov, 1962) mentions the presence of Arthropleura in Carboniferous deposits of the Karaganda Basin. In the message, it is emphasized that the remains have not yet been described.

On the scree of outcrop 3 trace fossils were also revealed, which can be defined as Diplichnites cuithensis Briggs, Rolfe et Brannan (fig. 8, 9).The remains and traces of locomotion of the giant arthropod Arhropleura are known mainly from limnic basins. Apparently, the conditions of the paralic Donets Basin contributed little to the widespread development of terrestrial fauna here, including Arthropleura.

In megaconcretion of carbonate sandstone from layer no. 2 outcrop 3, the imprint of a wing fragment of an undefined Paleodictyoptera was found (fig. 5, 4). This fossil was found in an accumulation of plant detritus, which were oriented by surf. Sandstones are extremely unfavorable for preserving insect remains. However, due to the mechanical strength of the wing and more intensive cementation of nodule sandstone compared to the lateral rock, the fossil has sufficient preservation for approximate determination. Paleodictyoptera are large and very large flying insects, the remains of which are known from Namurian B (= Lower Bashkirian) and ending with deposits of the Cisuralian. According to A. G. Sharov (1973), these insects lived in the crowns of tree-like pteridosperms and cordaitanth. They were feeding on the reproductive organs of these plants, in particular juices of immature seeds of Cordaitales. Apparently, many Carboniferous ovipositions confined to plant organs belong to Paleodictyoptera. These ovipositions were also discovered in Pennsylvanian sediments of the Donets Basin (unpublished data of the author).

In the nodule from siltstones of layer no. $6 \mathrm{~b}$ (outcrop 1), an imprint of an insect wing fragment was found. This fossil could not be determined due to the strong weathering of the nodule, which is why only a part of the venation is visible on the imprint.

$\leftarrow$ Fig. 7. Trace fossils and body remains of animals from the studied sandstones: 1 - Lockeia siliquaria James, 1879 (layer no. 8, outcrop 1; field photo); 2 - ?trace of swimming of Tetrapoda (layer no. 7, outcrop 1; sample no. 6938); 3 - Selenichnites isp. 4 (outcrop 3, scree; field photo); 4 - plant remains with traces of exposure to arthropods (outcrop 3, scree; sample no. 6774); 5 - remains of prosoma of the large horseshoe crab (layer no. 9, outcrop 1; sample no. D-10d); 6 - the foliage of Paripteris gigantea (Sternb.) with traces of marginal feedings of arthropods (siltstones above a sandstones under $\mathrm{G}_{1}{ }^{2}$, quarry $3 \mathrm{~km}$ west of outcrop 4; field photo); 7 - remains of the B-element of the Arthropleura sp. (layer no. 9, outcrop 1; no. 5476); 8 - indefinite arthropod remains from layer no. 7 (outcrop 1; field photo); 9 - indefinite arthropod remains (layer no. 9, outcrop 1; no. 5655); 10,11 - indefinite arthropod remains (layer no. 9, outcrop 1). The scale bar is $70 \mathrm{~mm}(1), 15 \mathrm{~mm}(2-4,7-10)$, $20 \mathrm{~mm}(5), 5 \mathrm{~mm}$ (6 and 12).

Рис. 7. Іхнофосилії та тілесні рештки тварин із вивчених пісковиків: 1 - Lockeia siliquaria James, 1879 (шар № 8, відслонення 1; польове фото); 2 - здогадно сліди плавання тетраподи (шар № 7, відслонення 1; зразок № 6938); 3 - Selenichnites isp. 4 (відслонення 3, осип; польове фото); 4 - рештки рослини зі слідами впливу членистоногих (відслонення 3, осип; зразок № 6774); 5 - рештки просоми крупного мечохвоста (шар № 9, відслонення 1; зразок № D-10d); 6 - пір’ячко Paripteris gigantea (Sternb.) зі слідами крайових об'їдань членистоногими (алевроліти вище пісковиків, що залягають під вапняком $\mathrm{G}_{1}^{2}$, кар'єр в 3 км західніше відслонення 4; польове фото); 7 - рештки Б-елементу членистоногого Arthropleura sp. (шар № 9, відслонення 1; зразок № 5655); 10, 11 - невизначені рештки артропод (шар № 9, відслонення 1). Масштабна лінійка - 70 мм (фіг. 1), 15 мм (фіг. 2-4, 7-10), 20 мм (фіг. 5) і 5 мм (фіг. 6 та 12). 
Insect remains are studied from Carboniferous deposits of the Donets Basin and the DnieperDonets depression rather poorly. Many paleontologists, mainly paleobotanists (for example, O. P. Fisunenko and A. K. Shchegolev (Fisunenko, 1987), indicated the presence of remains of "dragonflies" in Pennsylvanian deposits of the Donets Basin. E. O. Novik (1941) reported the find of an imprint of the cockroach wing in Pennsylvanian sediments exposed by one of the boreholes in the territory of Romny Raion (Sumy Oblast, Ukraine). The deposits in which the remains were found were compared with the upper part of the Gorlovka Formation and lower part of the Isaevka Formation (upper part of Moscovian Stage) of the Donets Basin. Complete imprint of the body of a dragonfly is known from marine dark gray mudstones of the upper part of the Dyakovska Series from vicinities of Dovzhans'k (south of Lugansk Oblast, Ukraine) (Dernov, 2016).

The only species of Carboniferous insects described at the moment from the territory of the Donets Basin is the Paleodictyoptera Spilaptera tanaica Sharov et Sinitshenkova, 1977 found in deposits of the Isaevka Formation (Lower Kasimovian) of the Lomovatka site (Sharov, Sinichenkova, 1977). Insect finds are not abundant, although the Donets Basin is quite promising for new finds of insect remains.

Other invertebrates. In the upper part of layer no. 9 (outcrop 1), a body imprint supposedly of a freshwater jellyfish Medusina was found (fig. 5, 5). The remains of these animals are known from Cisuralian lakustrine sediments of limnic basins of the Czech Republic, Germany, France, and Italy (Gand et al., 1996; Santi, 2010). The fact of the presence of well-preserved remains of freshwater jellyfish indicates a greatly reduced salinity of the waters of the basin, in which sediments of layer no. 9 were deposited. The good preservation of the body indicates, apparently, its rapid burial.

Vertebrates. In the nodule from siltstones of layer no. 6c (outcrop 1), an indefinite scale of Actinopterigia was found (fig. 5, 9).

Trace fossils of animals are often found in different layers of the studied outcrops and are relatively numerous there (fig. 7, 1-3; fig. 8, 2, 4, 5-7, 10-11). For example, the average density of burrows of Scolithos linearis (Haldeman) from the sandstone interlayer in layer no. 3 (outcrop 1) is 17 specimens $/ 25 \mathrm{~cm}^{2}$ of the layering surface. The density of pelecypods resting traces Lockeia siliquaria James from layer no. 4 is $7-20$ specimens $/ 1800 \mathrm{~cm}^{2}$; from layer no. $6 \mathrm{~d}$ is 8 specimens $/ 25 \mathrm{~cm}^{2}$ and from layer no. 8 is 10 specimens $/ 225 \mathrm{~cm}^{2}$. The total length of trace fossil Aulichnites isp. on the layering surfaces of layer no. 7 is $7-8 \mathrm{~cm} / 25 \mathrm{~cm}^{2}$. However, the bioturbation of the rocks is rather weak. For example, for the most part of the deposits of the outcrop 1 ichnofabric index is $1 / 5$ and only in some layers reaches $2 / 5$ and $3 / 5$. The composition of ichnocenoses is shown in Table 2.

\section{Table 2. The composition of ichnocenoses from the studied sandstones}

\section{Таблиия 2. Склад іхноценозів вивчених пісковиків}

\begin{tabular}{|c|c|}
\hline Outcrops & Trace fossils \\
\hline 1 & $\begin{array}{l}\text { Arenicolites isp., Aulichnites parkerensis Fenton et Fenton, Aulichnites isp., Conichnus isp., Diplocraterion isp., } \\
\text { Helicerina isp., Helminthopsis hieroglyphica Heer in Maillard, Helminthopsis isp., Lockeia siliquaria James, } \\
\text { Monocraterion isp., Planolites isp., Ptychoplasma isp., Rusophycus isp. 1, Rusophycus isp. 2, ?Sagittichnus isp., } \\
\text { Saerichnites isp., Scolithos linearis (Haldeman), Selenichnites cf. tesiltus Gibb, Chatterton et Pemberton, Sele- } \\
\text { nichnites isp. 1, Selenichnites isp. 2, Treptichnus pollardi Buatois et Mangano, Treptichnus isp., ?swimming trace } \\
\text { of Tetrapoda. }\end{array}$ \\
\hline 2 & Aulichnites isp., Planolites isp., Rhizocorallium isp. \\
\hline 3 & $\begin{array}{l}\text { Archaeonassa fossulata Fenton et Fenton, Arenicolites isp., Aulichnites isp., Bergaueria isp., Circulichnis mont- } \\
\text { anus Vyalov, Diplichnites cuithensis Briggs, Rolfe et Brannan, Diplopodichnus biformis Brady, Gordia marina } \\
\text { Emmons, Helminthopsis isp., Kouphichnium isp., Lockeia siliquaria James, ?Lophoctenium isp., ?Merostom- } \\
\text { ichnites isp., Monomorphichnus isp., ?Neonereites isp., Planolites isp., Ptychoplasma isp., Rhizocorallium isp., } \\
\text { Scolithos linearis (Haldeman), Selenichnites hundalensis (Romano et Whyte), Selenichnites isp. 3. }\end{array}$ \\
\hline 4 & $\begin{array}{l}\text { Bergaueria isp., Planolites isp., Rhizocorallium isp., Scolithos linearis (Haldeman), Selenichnites cf. tesiltus Gibb, } \\
\text { Chatterton et Pemberton. }\end{array}$ \\
\hline $6 \mathrm{~b}$ & Diplopodichnus biformis Brady, Planolites isp., Protovirgularia isp., Selenichnites isp. 4. \\
\hline 8 & Avetoichnus luisae Uchman et Rattazzi, Planolites isp. \\
\hline 9 & Arenicolites isp., ?Conichnus isp., Paleophycus isp., Rhizocorallium isp., Scolithos linearis (Haldeman). \\
\hline
\end{tabular}


In siltstones that directly overlap sandstones under $\mathrm{G}_{1}{ }^{2}$ in a quarry $3 \mathrm{~km}$ west of outcrop 4 , remains of pteridosperm Paripteris gigantea (Sternb.) with traces of marginal feedings of the millipedes or other arthropods were found (fig. 7, 6). In nodules from layer no. $6 \mathrm{~b}$ of outcrop 1 , the phyloid remains Cyperites bicarinatus Lindley et Hutton with galls on the surface are often found (fig. 5, 10). On outcrop 3, the imprint of a leaf with a clearly visible groove, divided by a longitudinal medial elevation (fig. 7,4 ) was found. The origin of this groove is unknown.

When studying outcrops 1 and 3, we repeatedly noted resting traces of horseshoe crabs Selenichnites Romano et Whyte, 1990 (fig. 7, 3; fig. 8, 1, 3, 8). Romano and White (2015) propose to separate similar trace fossils from the ichnogenus Selenichnites into ichnotaxon Crescentichnus Romano et Whyte, 2015 and some others. It is hard to agree with this point of view. We determined 6 forms of Selenichnites (see Table 2), which differ in size and morphology. It is difficult to establish the ichnospecies affiliation of most of these ichnofossils due to the complexity of their parataxonomy. A recent revision of this ichnogenus (Romano, Whyte, 2015), in our opinion, only exacerbated the situation. It is likely that some of the traces we have identified are new ichnospecies. We focused on trace fossils of Selenichnites isp. 1 (fig. 8,1) and Selenichnites cf. tesiltus Gibb, Chatterton et Pemberton. Four trace fossils were studied: one isolated (S. isp. 1) and three concentrated in a group on an area of about $700 \mathrm{~cm}^{2}$ (S. cf. tesiltus). Apparently, the width of the prosoma of the horseshoe crabs that left these traces was not less than $15 \mathrm{~cm}$. For the Paleozoic horseshoe crabs, these are more than significant sizes (for example, the species Xaniopyramis linseyi Siveter et Selden described from Namurian deposits of Britain, with the prosoma width of about $15.5 \mathrm{~cm}$ was called "giant" by the authors (Siveter and Selden, 1987). Morphologically, the traces of Selenichnites cf. tesiltus are similar to Selenichnites isp., known from the Middle Jurassic of Morocco (Oukassou et al., 2015). The sizes of Moroccan ichnofossils are approximately the same as trace fossils from the Donets Basin. Selenichnites isp. 4 (fig. 8, 3), very similar to Selenichnites tesiltus, but having a triangular area was located behind the arched indentation left by the front edge of the horseshoe crab prosoma. Such morphological diversity of Selenichnites among rocks of a limited stratigraphic interval can be explained by the presence of individuals of different degrees of maturity in the same biotope and, obviously, of different species, which left traces of different size and morphology.

Noteworthy is the finding of a trace fossil in sandstones of layer no. 7 (outcrop 1), very similar to the swimming traces of tetrapods (fig. 7, 2). In Fillmore et al., 2012, such traces are identified as Characichnos isp.

Traces of Aulichnites are often observed on surfaces on which microbial sedimentation textures were also discovered. This fact, perhaps, testifies to the trophic attachment of gastropods represented by traces of Aulichnites to microbial mats. In Buatois, Mángano, 2016, four categories of interaction of organisms and microbial mats are identified. They, with slight changes, can be taken as a model for the deposits we studied. For layer no. 2 (outcrop 1), the category "mat grazers" can be distinguished. It includes Aulichnites isp. and Helminthopsis hieroglyphica. According to Buatois, Mángano, 2016, this category includes the ichnocommunity Helminthopsis (this includes trace fossils Helminthopsis, Helminthoidichnites, Archaeonassa, Gordia). Trace fossils that make up this community are abandoned by animals that feed on organic matter concentrated on the surface of microbial mats or under a thin layer of sediment.

In layer no. 7 of the same outcrop, one can distinguish the already mentioned category of "mat grazers" (Aulichnites isp., Helminthopsis isp.), as well as the category of "undermat miners": Treptichnus pollardi. It includes the ichnocommunity Treptichnus-Saerichnites (Treptichnus) represented by traces in the sediment just below the microbial mats. The same community is also characteristic for layer no. 8, in which Saerichnites bioturbations are found.

In addition to traces of animal activity, phytoturbations caused by the influence of plant root systems on sediment and confined to paleosol profiles were also noted in the studied sections. 


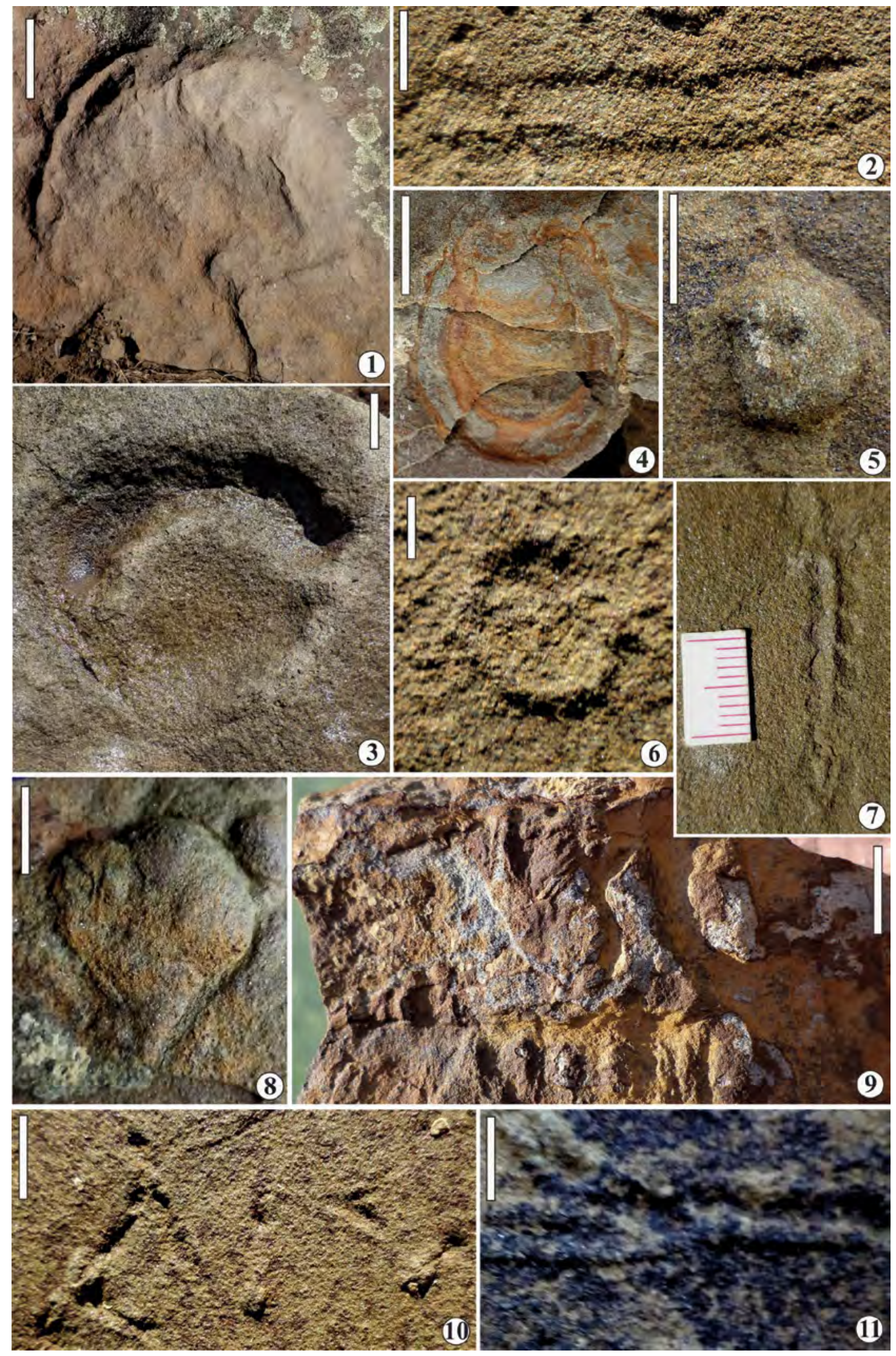


$\leftarrow$ Fig. 8. Some trace fossils from the studied sandstones: $1-$ Selenichnites isp.1 (layer no. 9, outcrop 1; field photo); 2 - Diplopodichnus biformis Braddy, 1947 (outcrop 3, scree; field photo); 3 - Selenichnites isp. 4 (layer no. 8, outcrop 6b; field photo); 4 - Rhizocorallium isp. (outcrop 3, scree; field photo); 5 - Bergaueria isp. (outcrop 3, scree; no. 6446); 6 - Circulichnis montanus Vyalov, 1971 (outcrop 3, scree; field photo); 7 - Avetoichnus luisae Uchman et Rattazzi, 2011 (layer no. 6, outcrop 8, field photo); 8 - Selenichnites isp. 3 (outcrop 3, scree; no. 6416); 9 - Diplichnites cuithensis Briggs, Rolfe et Brannan, 1979 (outcrop 3, scree; field photo); 10 - Treptichnus pollardi Buatois et Mangano, 1993 (layer no. 7, outcrop 1; field photo); 11 - Aulichnites isp. (layer no. 7, outcrop 1; sample no. 6545). The scale bar is $35 \mathrm{~mm}(1,4,9), 10 \mathrm{~mm}(2,3,5,10,11), 5 \mathrm{~mm}(6), 15 \mathrm{~mm}(8)$.

Рис. 8. Деякі іхнофосилії з вивчених пісковиків: 1 - Selenichnites isp.1 (шар № 9, відслонення 1; польове фото); 2 - Diplopodichnus biformis Braddy, 1947 (відслонення 3, осип; польове фото); 3 - Selenichnites isp. 4 (шар № 8, відслонення 6b, польове фото); 4 - Rhizocorallium isp. (відслонення 3, осип; польове фото); 5 Bergaueria isp. (відслонення 3, осип; зразок № 6464); 6 - Circulichnis montanus Vyalov, 1971 (відслонення 3, осип; польове фото); 7 - Avetoichnus luisae Uchman et Rattazzi, 2011 (шар № 6, відслонення 8; польове фото); 8 - Selenichnites isp. 3 (відслонення 3, осип; зразок № 6416); 9 -Diplichnites cuithensis Briggs, Rolfe et Brannan, 1979 (відслонення 3, осип; польове фото); 10 - Treptichnus pollardi Buatois et Mangano, 1993 (шар № 7, відслонення 1; польове фото); 11 - Aulichnites isp. (шар № 7, відслонення 1; зразок № 6545). Масштабний відрізок 5 мм (фіг. 6), 10 мм (фіг. 2, 3, 5, 10, 11), 15 мм (фіг. 8), 35 мм (фіг. 1, 4, 9).

The results of the study of trace fossils show that the sandstones were accumulated under conditions of at least three ichnofacies: Psilonichnus, Scolithos, and Cruziana. Psilonichnus Ichnofacies is common in the tidal zone at the border of marine and fresh waters (Mikuláš, Dronov, 2006). Scolithos ichnofacies is inherent in coastal environments with high hydrodynamic activity (Mikuláš, Dronov, 2006). The Cruziana ichnofacies is characterized by calmer sedimentation conditions compared to the Scolithos ichnofacies (Mikuláš, Dronov, 2006). Noteworthy the presence in the outcrop of stratigraphic intervals composed of sediments accumulated in extremely shallow, apparently periodically drained conditions. This is indicated by the presence of traces of terrestrial organisms (for example, ichnofossils of terrestrial arthropods Diplichnites and Diplopodichnus).

\section{Sedimentation conditions}

From all of the above information, it becomes clear that the two studied sandstone beds have significant litho-facial similarity, which is expressed by the similarity of lithotypes of rocks, the presence of carbonate megaconcretions and pebbles of metamorphic slates, paleosols, as well as almost identical paleontological filling of sediments. Of course, this similarity is caused by the similar conditions of sedimentation.

Outcrop 1. Layers no. 1 and 2 were formed under avandeltaic conditions. Since gray siltstones (layer no. 3) are often absent or their thikness is reduced, it follows that sedimentation was very uneven. Accumulation of sediments of layer no. 3 was of the intra-deltaic gulf with silt bottom, which was characterized by slow sedimentation, content of hydrogen sulphide in water and silt and complicated aeration of the water column that arose due to a rather calm hydrodynamic regime. The salinity of the bay was reduced due to the penetration of significant volumes of fresh water, enriched, moreover, with dissolved iron. An interlayer of sandstones in the siltstones of layer 3 was formed during a short-term decrease in the depth of the bay and, accordingly, an increase in water activity and an improvement in its aeration. The overlying sandstones of layer no. 4, apparently, were also formed under avandeltaic conditions.

The sandstones of layer no. 5, which form the PS-1/1 paleosol profile, are sediments of subaerial deltaic plain. The prevailing landscape of this situation, apparently - marshes, which were characterized by monotaxic groupings of tree-like lycopsids. Deposits of layer no. 6 were formed under conditions of an extensive desalinated lagoon with soft bottom silts, good aeration, and moderate sedimentation rates. The coastal zone of the lagoon (or lagoons) was inhabited by small horseshoe crabs. Bivalves lived in parts of the water area further from the coast. In the western part of the quarries, the PS-1/1a paleosol is observed, apparently lying within the subaerial bar, wich separate the lagoon from the shallow water marine basin. The overlying part of the section (layers no. 7 and 8) refers to the sediments of the avandelta. 


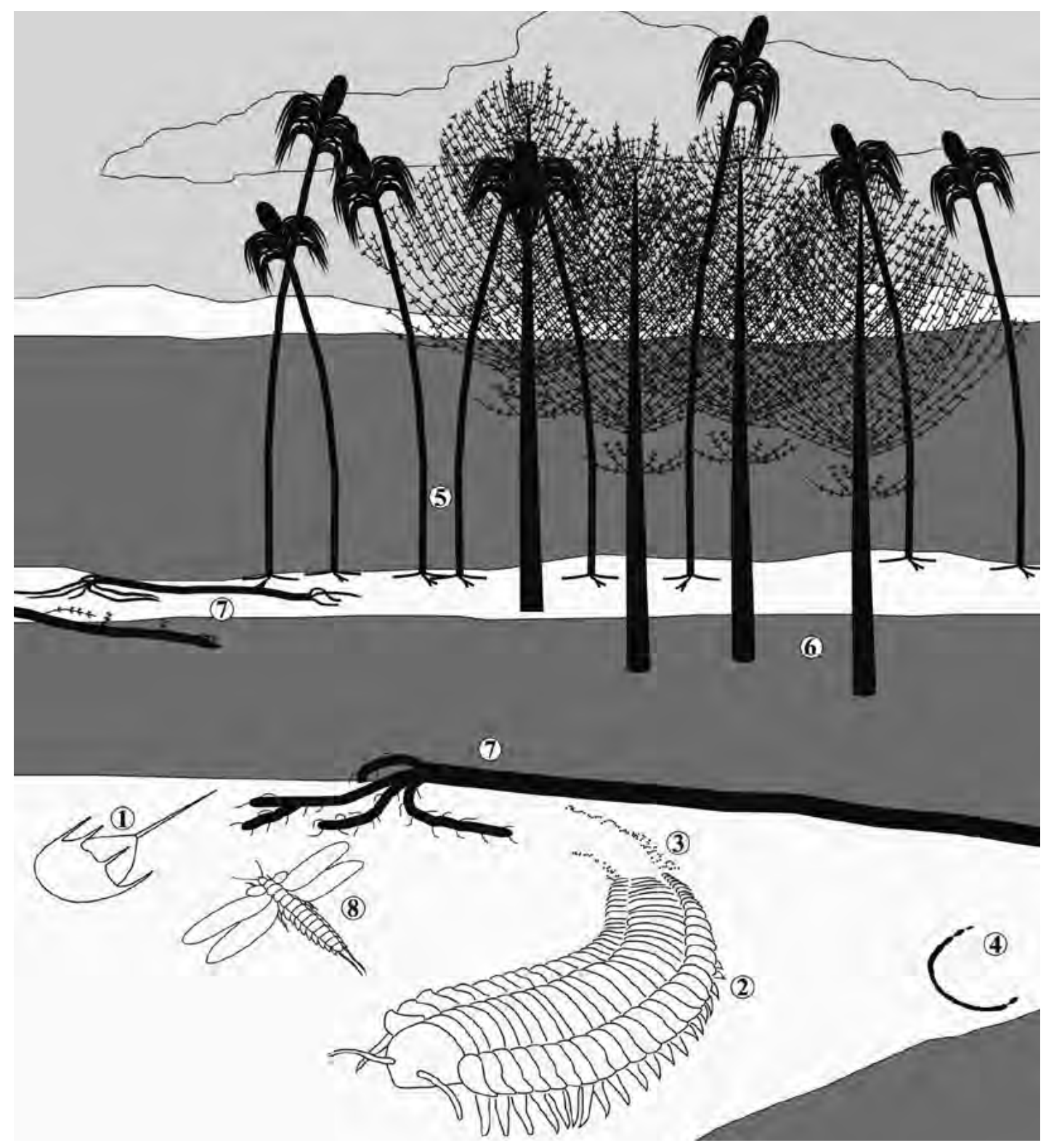

Fig. 9. Landscape of the accumulation time of sandstones of layers no. 9 (outcrop 1) and no. 2 (outcrop 2): 1 - large horseshoe crab, 2 - arthropod Arthropleura, 3 - Diplichnites cuithensis - traces of locomotion of Arthropleura, 4 - Selenichnites - traces of rest of horseshoe crabs, 5 - tree-like lycopsids, 6 - tree-like horsetails, 7 - windbreak (trunks of tree-like lycopsids and horsetails), 8 - insect of the order Paleodictyoptera; gray filling - water; white filling - land.

Рис. 9. Ландшафт часу накопичення пісковиків шару № 9 (відслонення 1) та № 2 (відслонення 2): 1 - крупний мечохвіст, 2 - артропода Arthropleura, 3 - Diplichnites cuithensis - сліди локомоції артропод Arthropleura, 4 - Selenichnites - сліди лежання мечохвостів, 5 - деревовидні лепідофіти, 6 деревовидні хвощеподібні, 7 - бурелом (стовбури деревовидних лепідофітів та хвощеподібних), 8 комаха ряду Paleodictyoptera; сірим кольором позначено воду, а білим - суходіл.

Apparently, for layer no. 9 (fig. 9), formation about conditions of a subaerial delta plain can be assumed. For rocks of the upper part of the layer, the accumulation environment can be detailed. Apparently, these sandstones were accumulated under conditions of an extensive gently sloping beach covered with thickets of semi-aquatic horsetails of the genus Calamites and located within the supralittoral. On land, they were replaced by tree-like lycopsids and pteridosperms, and by cordaitant and pteridosperms in more elevated sections of the coastal lowland. The described coast and coastal waters 
were the habitat of adult large horseshoe crabs, which were buried along with the remains of severely damaged flora and fragments of Arthropleura bodies. Remains of Arthropleura were delivered by streams from the surrounding flooded thickets of lycopsids. Significant desalination of the waters may be indicated by the find of remains of presumably fresh-water jellyfish in the upper part of layer no. 9. Siltstones of layer no. 10 can be attributed to prodeltaic deposits.

An analysis of trace fossils from the sandstones below the $\mathrm{G}_{1}^{2}$ limestone suggests a richer composition of organisms living near and at the deposition site of the studied sediments, but whose body remains were not found. Among them, worms, anemones, crustaceans, and amphibians should probably be noted.

Outcrop 2. Summarizing the obtained data, we can assume about the formation of sediments of layers no. 1 and 2 under avandeltaic conditions. Sandstones of layer no. 3 were formed on the subaerial deltaic plain. Layer no. 4 is represented by shelf sediments.

Outcrops 3 and 11. Siltstones of layer no. 1 are, apparently, sediments of prodelta. The sandstones of layers no. 2-4, 6, 7, 9, 11, 13, 14, and 16 are, apparently, avandeltaic formations. Siltstones of layer no. 5 are, apparently, lagoonal sediments. Phytoturbated sandstones of layers no. 8 and 8 a are deposits of the subaerial deltaic plain. Siltstones (layer no. 8b) are obviously deposits of the intra deltaic lagoon. Sandstones of layer no. 10 are deposits of the inclined part of the delta. Presumably, the lower part of layer no. 10 on the outcrop $6 \mathrm{~b}$ corresponds to the interbedded interlayer of prodeltaic siltstone. Coarse-grained sandstones of layer no. 12, which, despite varying thicknesses (from 1,5 to $3 \mathrm{~m}$ ), some variations in lithology and local presence at the base of a layer of coarse siltstone-fine-grained sandstone, are quite consistent in area and established by us as in the most western one, and the most eastern outcrops. Regarding the conditions of accumulation of these coarse-grained sandstones, we can only assume that these are sediments of the bar. Siltstones of layer no. 15 are apparently lagoonal deposits. Siltstones of layer no. 17 are sediments of the coastal swampy plain. Layer no. 18 is deposits of peat swamps.

\section{Conclusions}

1) Deltaic sandstone beds of different age of the Pennsylvanian of the Donets Basin sometimes demonstrate a significant degree of lithological and facies similarity, down to the smallest detail.

2) Significant variations of lithological sets of sediments and conditions of their accumulation in the section and in the space are observed within a single thickness of deltaic sandstones.

3) For the first time, paleosol are studied that occur among the deposits of the Bashkirian Stage of the Donets Basin.

4) Deltaic deposits are distinguished by the richness of oryctocenoses, which is associated with a variety of living conditions of organisms and the burial of their remains.

5) The presence of remains of the giant arthropod Arthropleura and supposedly jellyfish in Carboniferous deposits of the Donets Basin were revealed for the first time. The most diverse ichnocenosis from the Carboniferous of the Donets Basin was also studied. For some taxa of fossil plants, their stratigraphic distribution was detailed.

\section{Acknowledgments}

I express my sincere appreciation to M. I. Udovychenko (Luhansk) for comprehensive assistance in the course of research. I thank V. I. Poletaev (Kyiv) as well as I. V. Zagorodniuk (Kyiv) and the anonymous reviewers for their help in preparing the article for publication.

\section{References}

Andrée, K. 1910. Zur Kennthis der Crustaceen-Gattung Arthropleura Jordan und deren systematischer Stellung. Palaeontographica, 67-104.

Antoshkina, A. I., N. N. Ryabinkina, O. V. Valyayeva. 2017. Genesis of siderite nodules from the terrigenous sequence of the Lower Carboniferous in the Subpolar Urals. Lithology and mineral resources, 2: 130-144. (In Russian) 
Ayzenverg, D. Ye., N. Ye. Brazhnikova, Ye. O. Novik, A. P. Rotay, P. L. Shulga. 1963. Carboniferous stratigraphy of Donets Basin. Izdatel'stvo AN USSR, Kyiv, 1-184. (In Russian)

Beznosov, P. A., S. M. Snigirevskiy, S. V. Naugol'nykh, E. V. Lukshevich. 2018. Upper Devonian complex of deposits of the delta plain in Northern Timan, Bulletin of the IG Komi Scientific Center, Ural Branch of the Russian Academy of Sciences, 288 (1): 25-44. (In Russian)

Briggs, D. E. G., W. D. I. Rolfe, J. Brannan. 1979. A giant Myriapod trail from Namurian of Arran, Scotland. Palaeontology, 22 (2): 273-291.

Buatois, L. A., M. G. Mángano. 2016. Ediacaran ecosystems and the dawn of animals. The trace-fossil record of major evolutionary events. Springer, Dordrecht, 27-72.

Castro, M. P. 1997. Hallazgos de Arthropleura en el Estefaniense de la Peninsula Iberica. Revista Espanõla de Paleontologia, 12 (1), 15-22.

Chernyshev, B. I. 1931. Carbonicola, Anthracomya, and Najadites of Donets Basin. Geological Publishing House of the Main Geological Exploration Directorate, Moscow-Leningrad, 1-126. (In Russian)

Copeland, M. J. 1957. The Arthropod fauna of the Upper Carboniferous rocks of the Maritime Provinces. Memoirs of Geological Survey of Canada, 286: 1-110.

Davydov, V. I., J. L. Crowley, M. D. Schmitz, V. I. Poletaev. 2010. High-Precision U-Pb Zircon Age Calibration of the Global Carboniferous Time Scale and Milankovitch Band Cyclicity in the Donets Basin, Eastern Ukraine. Geochemistry, Geophysics, Geosystems, 11 (1): 1-22.

Dernov, V. S. 2013. Marks of the underwater landslips in the Middle Carboniferous deposits of Central part of Donets Basin and their scientific significance. Geographic public scientific research: past, present, future. Proceedings of the All-Ukrainian Scientific and Practical Conference on the 75th Anniversary of the Establishment of the Luhansk Region, Luhansk, 86-90. (In Ukrainian)

Dernov, V. S. 2015. New finds of arthropod remains and their traces in the Bashkirian deposits of Donets Basin. Paleontological Collection, 47: 120-126. (In Ukrainian)

Dernov, V. S. 2016. New data on the paleontological characteristics of deposits of the Dyakovska Group (Bashkirian Stage) of Donets Basin. Bulletin of the National Museum of Natural History, 14: 35-46. (In Ukrainian) DOI: $10.15407 /$ vnm.2016.14.035

Dernov, V. S. 2018. To the paleontological characteristics of the Smolyaninovka Formation (Middle Carboniferous: Donets Basin). Problems of the Phanerozoic geology of Ukraine. Proceedings of the IX AllUkrainian Scientific Conference (Lviv, October 10-12, 2018), Lviv, 36-39. (In Ukrainian)

Dernov, V. S., V. V. Khmyzova. 2016. Ichnocomplexes of the Dyakovska Group (Middle Carboniferous) of Donets Basin. Modern geological science and practice in studies of students and young professionals. Proceedings of the XIIth All-Ukrainian Scientific and Practical Conference (Krivoy Rog, March 24-26, 2016). Publishing Center of Krivoy Rog University, Krivoy Rog, 31-36. (In Russian)

Feofilova, A. P. 1966. Transition of coal-bearing deposits to salt-bearing in western part of Donets Basin. Nauka, Moscow, 1-176. (In Russian)

Feofilova, A. P. 1975. Fossil soils of Carboniferous and Perm of Donets Basin. Nauka, Moscow, 1-104. (In Russian)

Fillmore, D. L., S. G. Lucas, E. L. Simpson. 2012. Ichnology of the Mississippian Mauch Chunk Formation, eastern Pennsylvania. New Mexico Museum of Natural History and Science, 54: 1-136.

Fisunenko, O. P. 1973. Methodology and geological significance of ecological-taphonomic studies (on the example of the Middle Carboniferous of Donets Basin). Abstract of dissertation for the degree of Doctor of Geological and Mineralogical Sciences. Institute of Geological Sciences, Academy of Sciences of the Ukrainian SSR, Kiev, 1-44. (In Russian)

Fisunenko, O. P. 1987. Landscapes of the Middle Carboniferous of Donets Basin. Paleontology and reconstruction of the geological history of paleobasins. Nauka, Leningrad, 92-99. (In Russian)

Fisunenko, O. P., A. I. Reznikov. 1985. About new method of stratigraphy of flish-like beds of Carboniferous of Donets Basin. Fossil organisms and stratigraphy of sediments of Ukraine. Naukova Dumka, Kyiv, 34-38. (In Russian)

Gand, G., J., Garric, J., Schneider, J., Sciau, H. Walter. 1996. Biocoenoses à méduses du Permien francais (bassin de Saint-Affrique, Massif Central). Geobios, 29 (4): 379-400.

Getty, P. R., R. Sproule, M. R. Stimpson, P. C. Lyons. 2017. Invertebrate trace fossils from the Pennsylvanianaged Rhode Island Formation of Massachusetts. Atlantic Geology, 53: 185-206.

Gubin, Yu. M., V. K. Golubev, V. V. Bulanov, S. V. Petukhov. 2003. Tracks of pareiasaurs from the Upper Permian of Eastern Europe. Paleontological Journal, 5: 67-76. (In Russian)

Klappa, C. F. 1980. Rhizoliths in terrestrial carbonates: classification, recognition, genesis and significance. Sedimentology, 27: 613-629.

Klebanovich, N. V. 2015. Soils of the world in the WRB system: a workshop for students with specialties 1-56 0202. Minsk, 1-41. (In Russian)

Logvinenko, N. V. 1953. Lithology and paleogeography of the productive deposits of the Carboniferous of Donets Basin. Publishing House of Kharkov University, Kharkov, 1-436. (In Russian)

Makedonov, A. V., P. V. Zaritskiy. 1968. Concretions and concretional analysis. Methods of correlation of coalbearing strata and synonymy of coal seams. Nedra, Leningrad, 234-260. (In Russian)

Mikulás R., A. Dronov. 2006. Palaeoichnology - Introduction to the study of trace fossils. Academy of Sciences of Czech Republic, Pragum 1-122. 
Mladentsev, G. D., L. F. Narkelyun. 1958. First find of tetrapods footprints in the Upper Paleozoic sandstones of Dzhezkazgan. Priroda, 5: 72-74. (In Russian)

Nemyrovska, T. I., V. I. Efimenko. 2013. Middle Carboniferous (Lower Pennsylvanian). In: Gozhyk P. F. (Ed.). Stratigraphy of the Upper Proterozoic and Phanerozoic of Ukraine. Volume 1. Stratigraphy of the upper Proterozoic, Paleozoic and Mesozoic. Kyiv, 283-303. (In Ukrainian)

Nevesskaya, L. A., S. V. Popov, I. A. Goncharova, A. V. Guzhov, B. T. Yanin, I. V. Polubotko, A. S. Byakov, V. A. Gavrilova. 2013. Bivalve mollusks of Russia and neighboring countries in the Phanerozoic. Nauchnyy mir, Moscow, 1-524. (In Russian)

Nelikhov, A. 2010. In the dungeons of Dzhezkazgan. PaleoMir, 1 (8): 60-69. (In Russian)

Novik, Ye. O. 1941. On the issue of stratigraphy and lithology of Carboniferous deposits of the Romny district. Materials on the oil and gas potential of the Dnieper-Donets depression, 1: 201-217. (In Russian)

Novik Ye. O. 1952. Carboniferous flora of the European part of the USSR. Publishing House of the Academy of Sciences of the USSR, Moscow, 1-468. (In Russian)

Novozhylov, N. 1962. Family Arthropleuridae Zittel, 1848. In: Rodendorf B. B. (Ed.). Fundamentals of paleontology. Arthropods. Tracheata and Chelicerata. Publishing House of the Academy of Sciences of the USSR, Moscow, 25. (In Russian)

Oukassou, M., A. Charrière, A. Lagnaoui, S. Gibb, A. Michard, O. Saddiqi. 2015. The ichnogenus “Selenichnites" from the Middle Jurassic (Bathonian) strata of the Skoura syncline (Middle Atlas, Morocco). Arabian Journal of Earth sciences. Special issue. First International Congress on continental ichnology, 67-68.

Poletaev, V. I., V. G. Vakarchuk, L. G. Vinnichenko, L. P. Kononenko, A. Ye. Lukin, A. I. Reznikov. 1991. Separation and correlation of different facial strata of the Lower and lower part of the Middle Carboniferous of Dnieper-Donetsk aulacogen. IGS. Academy of Sciences of the Ukrainian SSR, Kyiv, 1-52. (In Russian)

Pruvost, P. 1919. Introduction á l'Etude du terrain hoiller du Nord et du Pas-de-Calais: La Faune continentale du terrain hoiller du Nord de la France. Imprimerie Nationale, Paris, 1-804.

Romano, M., M. A. Whyte. 2015. A review of the trace fossil Selenichnites. Proceedings of the Yorkshire Geological Society, 60: 275-288.

Santi, G. 2010. Note su Medusina limnica Müller, 1978 e Medusina atava (Pohlig, 1892) Walcott, 1898 del Permiano inferiore continentale del Sudalpino (Italia settentrionale). Naturalista Valtellinese, 21: 29-47.

Schieber, J., P. K. Bose, P. G. Eriksson, S. Banerjee, S. Sarkar, W. Altermann, O. Catuneau. 2007. Atlas of microbial mat features preserved within the clastic rock record. Elsevier, Amsterdam, 1-311.

Schneider, J. W., S. G. Lucas, R. Werneburg, R. Rößler. 2010. Euramerican Late Pennsylvanian/Early Permian Arthropleurid/Tetrapod associations - implication for the habitat and paleobiology of the largest terrestrial arthropod. New Mexico Museum of Natural History and Science Bulletin, 49: 49-70.

Schneider, J. W., R. Werneburg. 2010. Arthropleura, der größte landlebende Arthropode der Erdgeschichte neue Funde und neue ideen. Semana, 25: 61-86.

Selden P. A., D. E. Shcherbakov, J. A. Dunlop, K. Yu. Eskov. 2014. Arachnids from the Carboniferous of Russia and Ukraine, and the Permian of Kazakhstan. Paläontologische Zeitschrift, 88 (3): 297-307.

Sergeyeva, M. T. 1969. Bivalves of the Upper Visean, Namurian and Bashkirian deposits of Great Donets Basin. Naukova Dumka, Kyiv, 1-144. (In Russian)

Sharov, A. G. 1973. Morphological features and lifestyle of the Palaeodictyoptera. Issues of paleontology of insects. Nauka, Leningrad, 49-63. (In Russian)

Sharov, A. G., N. D. Sinichenkova. 1977. New Palaeodictyoptera from the territory of USSR. Paleontological Journal, 1: 48-63. (In Russian)

Shpinyov, Ye. S. 2018. New data on the Carboniferous horseshoe crabs (Xiphosura, Chelicerata) of Donets Coal Basin. Paleontological Journal, 3: 49-62. (In Russian)

Shulha, P. L. 1948. Freshwater bivalves of Carboniferous deposits of the western part of Donets Basin. Publishing House of the USSR Academy of Sciences, Kyiv, 1-62. (In Ukrainian)

Shear, W. A., J. Kukalová-Peck. 1990. The ecology of Paleozoic terrestrial arthropods: the fossil evidence. Canadian Journal of Zoology, 68: 1807-1834.

Siveter, D. J., P. A. Selden. 1987. A new, giant xiphosurid from the lower Namurian of Weardale, County Durham. Proceedings of the Yorkshire Geological Society, 46 (2): 153-168.

Whyte, M. A. 2018. Mating trackways of a fossil giant millipede. Scottish Journal of Geology, 54: 63-68.

Yesenov, Sh. Ye., Ye. D. Shlygin (Eds). 1972. Geology of the USSR. Central Kazakhstan. Book 1. Nedra, Moscow, 1-532. (In Russian)

Yes'kov, K. Yu. 2008. Amazing paleontology. ENAS, Moscow, 1-312. (In Russian)

Zaritskiy, P. V. 1959. Concretions of coal-bearing deposits of Donets Basin. Publishing House of Kharkov University, Kharkov, 1-240. (In Russian)

Zerov D. K., K. O. Novyk, N. O. Shchekina, K. O. Kovalenko. 1972. To the century of paleobotanical researches in Ukraine. Bibliographic index (1872-1971). Naukova Dumka, Kyiv, 1-120. (In Ukrainian) 